INTERNATIONAL MONETARY FUND
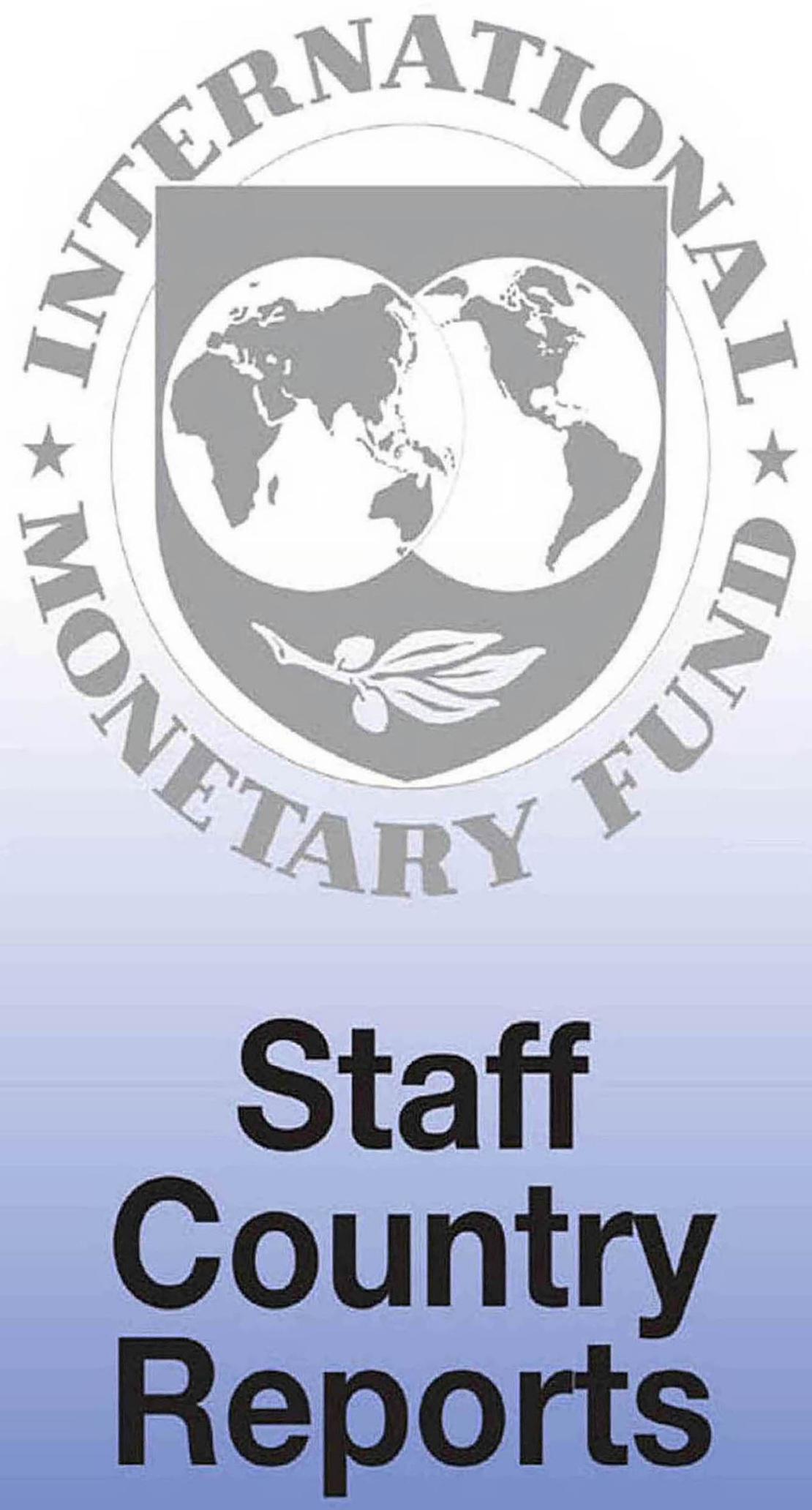


\section{Republic of Latvia: Ex Post Evaluation of Exceptional Access Under the 2008 Stand-By Arrangement; Public Information Notice on the Executive Board Discussion; and Statement by the Executive Director for the Republic of Latvia}

The following documents have been released and are included in this package:

- The Ex Post Evaluation of Exceptional Access under the 2008 Stand-By Arrangement on Latvia prepared by a staff team of the International Monetary Fund. It is based on the information available at the time it was completed on December 19, 2012. The views expressed in this document are those of the staff team and do not necessarily reflect the views of the government of Latvia or the Executive Board of the IMF.

- A public Information Notice (PIN) summarizing the views of the Executive Board as expressed during its January 23, 2013 discussion of the Ex Post Evaluation. The PIN also includes the views of the Executive Board expressed during this meeting on the staff report on the 2012 Article IV Consultation and Second Post-Program Monitoring Discussions.

- A statement by the Executive Director for the Republic of Latvia.

The policy of publication of staff reports and other documents allows for the deletion of marketsensitive information.

Copies of this report are available to the public from

International Monetary Fund • Publication Services $70019^{\text {th }}$ Street, N.W. • Washington, D.C. 20431

Telephone: (202) 623-7430 • Telefax: (202) 623-7201

E-mail: publications@imf.org Internet: http://www.imf.org

\section{International Monetary Fund Washington, D.C.}


INTERNATIONAL MONETARY FUND

REPUBLIC OF LATVIA

\section{Ex Post Evaluation of Exceptional Access \\ Under the 2008 Stand-By Arrangement}

Prepared by an Interdepartmental Staff Team ${ }^{1}$

Authorized for Distribution by the European Department and the Strategy, Policy, and Review Department

December 19, 2012

Contents

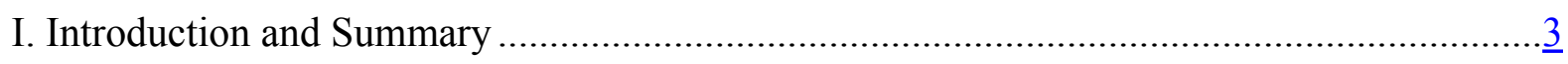

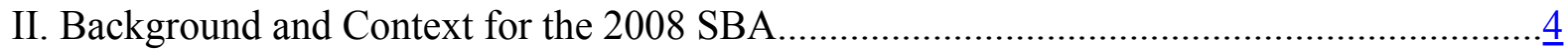

III. Appropriateness of Program Design ............................................................................

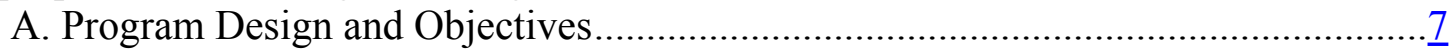

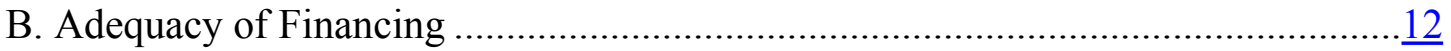

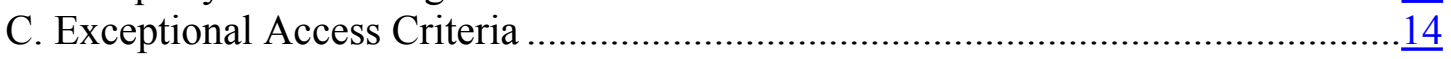

D. Appropriateness of Conditionality ………………………................................

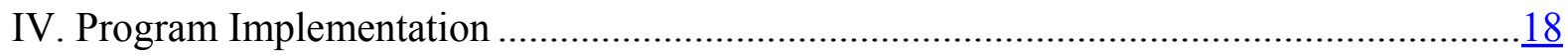

A. Macroeconomic Projections..............................................................................

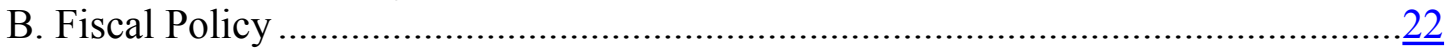

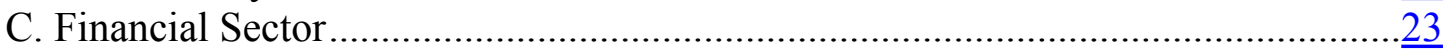

D. Monetary and Exchange Rate Policy ...................................................................

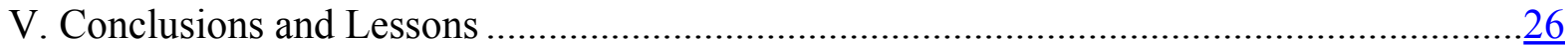

Tables

1. Prior Actions, Structural Performance Criteria, and Structural Benchmarks under the 2008

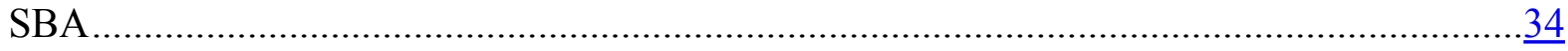

2. Quantitative Performance Criteria, Indicative Targets and Continuous Performance

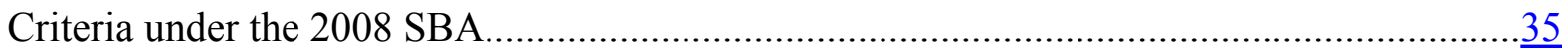

\footnotetext{
${ }^{1}$ The team comprised Said Bakhache (head, SPR), Eduardo Castro (EUR), Vassili Prokopenko (MCM), and Brett Rayner (SPR).
} 
3. Selected Economic Indicators, 2008-12

Figures

1. Selected Indicators, 2003-08

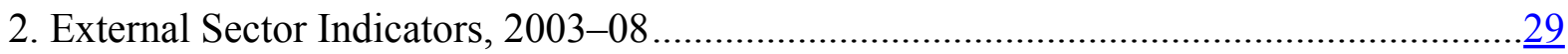

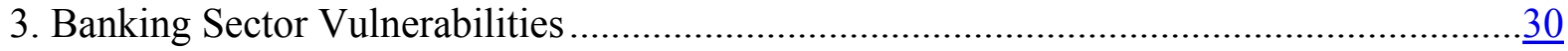

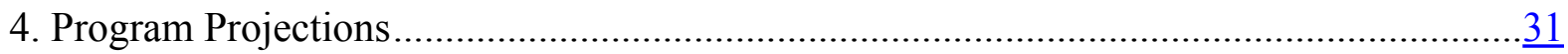

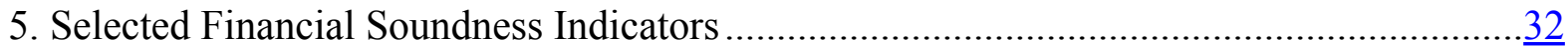

6. The Post-Crisis Banking Sector Deleveraging ................................................................

Boxes

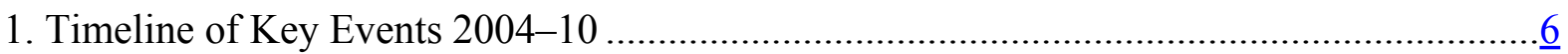

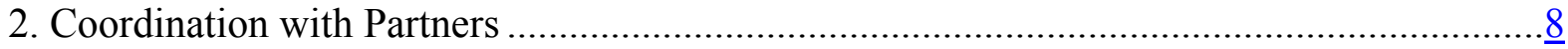

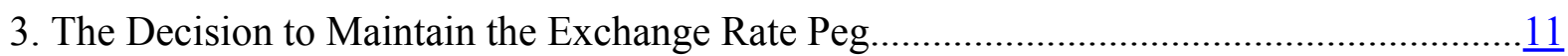

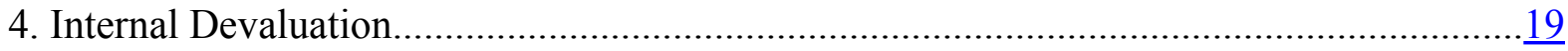

Annex

I. The Latvian Authorities' Views on the Ex-Post Evaluation 


\section{INTRODUCTION AND SUMMARY}

1. The Fund approved an exceptional access Stand-By Arrangement for Latvia on December 23, 2008 under the Emergency Financing Mechanism. Program access was set at 1,200 percent of quota (SDR 1.52 billion or approximately $€ 1.7$ billion) for a duration of 27 months, which was extended to 36 months at the time of the second review. The program request was made as Latvia was suffering from a sudden stop in capital inflows in the context of a fixed exchange rate regime, the initial response to growing liquidity problems in the largest domestically-owned bank failed to contain the deposit run, and international reserves were under severe pressure.

\section{The program was part of a coordinated international effort to stem the impact} of the economic bust that threatened financial and economic stability. It aimed to (i) arrest the loss of reserves and bank deposits; (ii) restore confidence in the banking sector, which was facing unprecedented vulnerabilities after years of exceptional credit growth and reliance on foreign sources of funding; (iii) limit the substantial widening of the fiscal deficit to create space for contingent liabilities and prepare for fulfillment of the Maastricht criteria; and (iv) rebuild competitiveness under the fixed exchange rate regime through income policies and structural reforms. The program was co-financed and coordinated with the European Union, EBRD, the World Bank, Nordic countries, and other neighboring countries with total program financing of $€ 7.5$ billion.

3. Supported by strong ownership, a large financing package, flexible design, and cooperation from the official and financial sectors, the immediate program objectives were met and progress was made in meeting the longer-term objectives. Increased uncertainty, including regarding the authorities' commitment to program objectives at the early stages of the program, gave way to better policy implementation and a sharp improvement in financial conditions relative to program projections, particularly after the first review. The loss of reserves and drain on bank deposits were stemmed by the third quarter of 2009. While the economic contraction and level of unemployment were much larger than initially projected, the turnaround in the current account was significant and fast. This helped reduce balance of payments pressures throughout the program period. By the third review of the program the authorities decided to treat the program as precautionary. More remains to be done, however, as unemployment remains high and output below potential.

4. This report assesses the effectiveness of the 2008 SBA for Latvia. Fund policy requires an ex-post evaluation (EPE) of General Resources Account-supported programs with exceptional access within a year after the end of the arrangement. Section II describes the developments leading to the crisis. Section III discusses key aspects of program design including objectives, conditionality, and financing, and examines the adequacy of the assessment of the exceptional access criteria. Section IV assesses policy implementation 
under the program. Section V concludes and suggests lessons that could be drawn from the experience of Latvia.

\section{BACKGROUND AND CONTEXT FOR THE 2008 SBA}

\section{The economic boom that began in $\mathbf{2 0 0 0}$ and accelerated following accession to} the European Union in 2004 proved unsustainable (Figures 1-3). Annual real growth averaged about 8.5 percent between 2000 and 2007. Post Russian crisis adjustment and the prospects for and eventual entry to the European Union (EU) helped catalyze confidence in the Latvian institutions and economy. The resulting private sector inflows fueled rapid economic growth driven mainly by domestic demand in the nontradeable sector. Inflation accelerated, a real estate bubble developed, and a large current account deficit opened peaking at about 23 percent of GDP in 2007. The accompanying increase in foreign indebtedness, which financed domestic credit expansion, led to the buildup of vulnerabilities particularly in the banking sector and heightened financial account risks. Gross external debt of the banking sector reached 87 percent of GDP at end-2007.

6. The economic expansion was financed with excessive bank credit growth. In the mid-2000s, bank credit grew at over 50 percent per year and was funded largely by external borrowing. Subsidiaries of large Swedish and other Nordic banks borrowed mainly from their parents, while locally-owned banks relied on short-term syndicated loans and deposits from non-residents. Bank loans were predominantly denominated in foreign currency and a large share represented household mortgages. By end-2007, the household debt-to-GDP ratio exceeded 40 percent, up from about 11 percent in 2003, the majority of which was mortgage debt (about 31 percent of GDP).

\section{Evidence of a loss of competitiveness was becoming clear starting in 2006.}

According to staff estimates, the real effective exchange rate (average of CPI, PPI, and ULCbased measures) appreciated by about 30 percent between early 2006 and end-2008. Wage and price pressures, along with limited increases in productivity, had eroded much of the competitiveness gains that Latvia enjoyed earlier in the decade. The trade deficit rose sharply and reached almost 24 percent of GDP in 2007.

8. Fiscal policy was accommodative as expenditures were rising rapidly. While the headline primary balance was in surplus (and public debt low and stable) until 2008 on the back of strong revenue performance, the structural balance turned negative starting in 2006. Overall expenditure doubled in real terms between 2001 and 2007.

\section{Article IV consultation and FSSA reports provided candid and timely alerts} about the building vulnerabilities. The 2006 Article IV staff report noted a significant overheating of the economy and called for policy tightening in order to contain the pressures and secure a soft landing. The March 2007 FSAP update also highlighted significant risks to systemic financial stability and called for a prompt and comprehensive policy action including effective cooperation between the Latvian authorities and the supervisory 
authorities of parent banks. In a candid press release at the end of the 2007 Article IV mission" ${ }^{2}$ staff also warned that "rapid credit growth in euros has left large currency mismatches on the balance sheets of households and corporates and a boom in housing prices that has diverted resources from the tradable sector."”

\section{The Latvian authorities remained sanguine in the face of these vulnerabilities} and only partial corrective measures were taken. The authorities viewed rapid GDP and credit growth as part of convergence to the EU average levels. Policy action to contain the mounting risks was therefore limited relative to the size of the macro imbalances and vulnerabilities. Some policy measures were even pro-cyclical, including an abolishment of the limits on banks' net open positions in the euro in 2005. These limits were subsequently reinstated, and some prudential and tax measures were introduced in March 2007. Fiscal policy generally remained accommodative, but pressure was mounting by mid-2008. In addition to an increase in real estate taxes, a supplementary budget in mid 2008 included net expenditure cuts of $1 / 2$ percent of GDP in the face of a much wider revenue shortfall.

\section{By early 2008, the fast growth was leveling off but severe vulnerabilities turned}

the slowdown into a crisis. Capital flows came to a sudden stop as global liquidity tightened following the failure of Lehman Brothers in September 2008. While pressure on foreign (mostly Swedish)-owned banks was stemmed through action by the Swedish government to support the parent banks, uncertainty over the financial condition of Parex Bank-the second largest bank and largest domestically-owned bank-led to a run on its deposits (a 25 percent decline between August and end-November 2008) and a severe system-wide liquidity shortage. These pressures were compounded by concerns over the sustainability of the currency peg and led to a simultaneous currency and bank run. In October, Latvia was downgraded by two credit rating agencies, CDS spreads reached 1,000 basis points and the interbank rates doubled to 8 percent. In November, reserves dropped by $€ 800$ million, about $1 / 2$ of total banks' required reserves at the central bank (see Box 1 for a timeline of key events).

12. Initial attempts to stem the crisis were not effective. The authorities' attempt to partially nationalize Parex Bank proved inadequate and deposits continued to fall until withdrawal restrictions on Parex deposits were imposed in early December 2008. Pressure on international reserves also continued. In November 2008, the authorities turned to the Fund and the European Commission for financial support to avert a systemic bank failure, prevent

\footnotetext{
${ }^{2}$ http://www.imf.org/external/np/sec/pr/2007/pr0787.htm.

${ }^{3}$ These risks and vulnerabilities as well as the significant real exchange rate overvaluation were also highlighted in the 2008 Article IV consultation report, which was issued to, but not discussed by, the Board. See paragraph 13 below.
} 
further decline in international reserves that could threaten the sustainability of the peg, and address the deterioration in the fiscal position in the face of the decline in economic activity.

\section{Box 1. Latvia: Timeline of Key Events 2004-10}

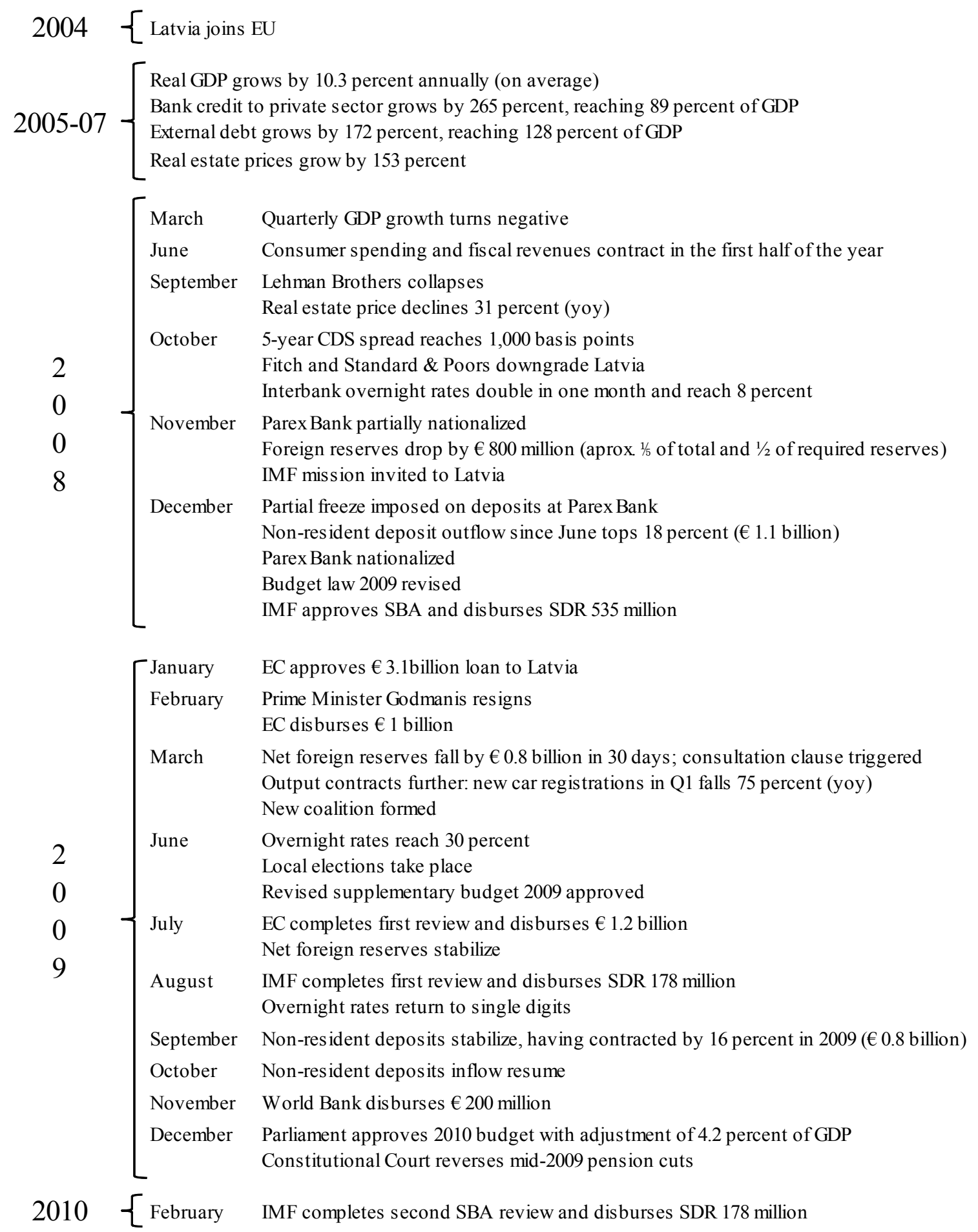




\section{The period leading to the request for Fund assistance was marked by a} complicated relationship with the authorities. Issues related to the implementation of the 2007 Bilateral Surveillance Decision - primarily regarding the finding of real exchange rate overvaluation - took center stage in the relations between the Fund and the authorities and led to significant delays in concluding the Article IV consultation. After long delays since the conclusion of the 2006 consultation, the 2008 Article IV report was issued to the Board in September 2008 but it was never discussed and therefore the consultation was not concluded. The unfolding of the crisis and program negotiations took precedence and the next Article IV consultation was concluded in July 2010.

\section{Appropriateness of Program Design}

\section{A. Program Design and Objectives}

14. The SBA's main objectives were to arrest the immediate liquidity crisis and then ensure long-term external stability, while maintaining the exchange rate peg. The program included immediate measures to stabilize the financial sector and restore depositor confidence, drawing on front-loaded official external support to bolster liquidity and help maintain foreign exchange reserves. For the medium term, the program included measures to foster real depreciation, including through income policies, and adjust fiscal policy to limit financing needs and create space to accommodate potentially large contingent financial sector liabilities. The program contained an explicit exit strategy of fulfillment of the Maastricht deficit criteria to facilitate euro adoption and help prevent recurrence of the financial and balance of payments crisis. This exit strategy heavily influenced the design of the fiscal program.

15. The program was coordinated with other partners (Box 2). The European Commission was heavily involved in program design, especially in the fiscal and financial sectors. The World Bank provided inputs on social safety nets and the financial sector legal framework while the EBRD was involved in the resolution of Parex Bank. At the technical level, a representative of the Swedish Ministry of Finance (a key partner given the significant importance of Swedish banks in Latvia) also regularly joined program missions.

\section{Immediate steps to stabilize the financial sector and help stem reserve losses} focused on resolving the systemic Parex Bank, which was experiencing a deposit run. Just before program approval, the government completed the takeover of 85 percent of Parex shares and appointed new professional management to run the bank and develop a strategy to return the bank to the private sector. Staff recommended that the government err on the side of overcapitalizing the bank, by raising its capital adequacy ratio to at least 12 percent. 


\section{Box 2. Coordination with Partners}

The European Commission was heavily involved in program design, especially in the fiscal and financial sectors. EU conditionality complemented and supplemented IMF conditionality. In particular, fiscal measures included steps to reduce the general government deficit below 3 percent of GDP consistent with exiting the Excessive Deficit Procedure, as well as measures to strengthen fiscal governance and public financial management. Financial measures focused on the bank resolution strategy. At the technical level, a representative of the Swedish Ministry of Finance, on behalf of the Nordic governments, also regularly joined program missions.

The World Bank provided inputs on social safety nets and the financial sector legal framework. The World Bank provided financing to Latvia under Development Policy Lending (DPL) for financial and social sectors and delivered technical assistance, most notably in the form of a Public Expenditure Review of government administration and the social sectors. The DPLs and technical assistance were coordinated with the IMF and the EC to ensure consistency.

The EBRD was involved in the resolution of Parex Bank. In April 2009, the EBRD acquired 25 percent plus one share in Parex Bank. This investment was seen as crucial to improving confidence in the bank and - given the large size of the bank - in the Latvian financial sector generally. The EBRD also provided a loan to Parex and assisted with the establishment of Loan Workout/Corporate Recovery Unit. It maintained a 25 percent ownership share in Citadele Bank, which was created using healthy assets from Parex Bank.

In addition, all of the above institutions cooperated in extending the "Vienna" Initiative to Latvia. In September 2009, the European Commission and the IMF jointly chaired a European Bank Coordination Meeting for Latvia. The World Bank, EBRD, the European Investment Bank (EIB), the International Finance Corporation, the Bank of Latvia, the Financial and Capital Markets Commission of Latvia, the Ministry of Finance of Latvia, home country authorities (Denmark, Finland, Norway and Sweden), and the European Central Bank (ECB) also attended the meeting. The key foreign banks active in Latvia-DnB Nord, Nordea, SEB and Swedbank - issued a Concluding Statement on the principles of maintaining their overall exposure to the country and meeting liquidity and capital needs of their branches and subsidiaries in Latvia.

\section{The program also aimed to reduce vulnerabilities in the rest of the banking}

system. It included commitments from foreign banks to maintain their exposures in Latvia. Swedish and other Nordic parent banks issued public statements with commitments to support their investments in the Latvian banking system. In addition, the bank regulator, FCMC, agreed to supervise a targeted examination of all banks - with a focus on domestic banks - by independent auditors to identify viable banks. This was complemented by the top down stress testing of banks performed by the Bank of Latvia (BoL). The purpose of this exercise was to identify non-viable banks and to require viable banks that needed capital to seek private restructuring via outside investors or mergers, or support from parent banks and shareholders. 
18. To mitigate solvency risks, the program envisaged measures to facilitate private debt restructuring. This included: (i) amending the insolvency law to facilitate workouts between viable enterprises and their creditors; (ii) improving the personal bankruptcy framework to help the rehabilitation of household debtors; and (iii) strengthening banks so that they can restructure their debts, including through debt-equity swaps and by transferring losses to foreign parent banks.

\section{Measures to ensure long-term external viability focused on fiscal and income}

policies. The original program included substantial and front-loaded fiscal adjustment to reduce aggregate demand, promoting real devaluation and a more viable external current account over the medium term and creating space for additional capital injections to domestic banks. To improve competitiveness, the program included wage and bonus reductions for central government employees by 25 percent. The authorities also undertook to expand wage cuts to state-owned enterprises and local governments by reducing transfers.

20. While the authorities expressed an unwavering commitment to the exchange rate peg, the issue was debated widely and extensively. There were significant concerns over the sustainability of the peg, including the ability to implement the necessary significant fiscal adjustment and

\begin{tabular}{|c|c|c|c|c|c|c|}
\hline \multicolumn{7}{|c|}{$\begin{array}{l}\text { Composition of Fiscal Adjustment } \\
\text { (Change in the primary balance) }\end{array}$} \\
\hline & \multicolumn{2}{|c|}{ In percent of GDP } & \multicolumn{4}{|c|}{ In percent of adj. } \\
\hline & 2009 & 2010 & Latvia & Hungary & Romania & Other $^{1}$ \\
\hline Total consolidation & 7.1 & 1.1 & 100.0 & 100.0 & 100.0 & 100.0 \\
\hline Revenue & 2.5 & 0.9 & 41.9 & -66.7 & 0.0 & 24.4 \\
\hline Direct taxes & -0.2 & 0.8 & 7.9 & -33.3 & -50.0 & 4.6 \\
\hline Indirect taxes & 2.4 & 0.1 & 29.8 & -33.3 & 50.0 & 8.5 \\
\hline Non-tax revenue & 0.3 & 0.0 & 4.2 & 0.0 & 0.0 & 11.3 \\
\hline Expenditure & 4.6 & 0.1 & 58.1 & 166.7 & 100.0 & 75.6 \\
\hline Primary current expenditure & 4.6 & 0.1 & 57.0 & 153.3 & -50.0 & 48.1 \\
\hline of which: wages & 1.3 & 0.4 & 20.8 & 73.3 & 233.3 & 9.4 \\
\hline Capital expenditure & 0.0 & 0.1 & 1.1 & 13.3 & 150.0 & 27.5 \\
\hline
\end{tabular}
controversial income policies, and the potential for a protracted recession. However, on balance, it was considered the most viable strategy to help restore confidence given (i) the strength of the domestic commitment to the peg, which was critical for program ownership, (ii) concerns over the impact of a devaluation on banks and their clients, and (iii) concerns over potential regional spillover effects of a devaluation which also underpinned the EU support for the peg (Box 2). ${ }^{4}$

\section{The strategy of maintaining the exchange rate peg and relying on internal} adjustment to deliver external sustainability came with significant risks. In particular, staff reports emphasized the importance of delivering the required fiscal adjustment, and the likely heavy output cost that would result and could affect public support for this strategy. In addition, staff emphasized the key importance of wage restraint by the private sector and local governments, where the central government had relatively little leverage.

\footnotetext{
${ }^{4}$ This report does not analyze the optimality of the exchange rate peg as an anchor to restore external and domestic balances, or the implications of maintaining the peg for the long run. Both are beyond the scope of the EPE.
} 
22. At the time of the first review, adjustments had to be made to program design in response to a significantly worse-than-expected economic contraction. ${ }^{5}$ The initial program design was based on an expected output contraction of 5 percent in the first year of the program. Instead, output contracted by 18 percent, which, along with partial implementation of agreed expenditure measures, led to significant fiscal underperformance. Staff therefore reconsidered the fiscal strategy to recognize the severe effects of the downturn and limit social costs particularly on vulnerable groups, while maintaining the exit strategy of fulfilling the Maastricht criteria. Changes to program design in subsequent reviews were relatively minor and focused on improving public expenditure efficiency and social safety nets and addressing emerging problems in the banking sector.

\begin{tabular}{lrrrrr}
\multicolumn{3}{c}{$\begin{array}{c}\text { Initital Output Projections and Outcomes } \\
\text { (Annual growth rate, in percent) }\end{array}$} \\
\cline { 2 - 3 } \cline { 5 - 6 } \cline { 5 - 6 } \cline { 5 - 6 } \cline { 5 - 6 } & \multicolumn{2}{c}{2009} & & \multicolumn{2}{c}{2010} \\
\cline { 2 - 3 } \cline { 5 - 6 } Real GDP & -5.0 & -17.7 & & -3.0 & -0.9 \\
Private consumption & -7.5 & -22.6 & & -6.0 & 2.4 \\
Public consumption & -3.0 & -9.4 & & -3.0 & -7.9 \\
Gross fixed investment & -12.0 & -37.4 & & -8.5 & -18.1 \\
Stockbuilding & -0.1 & -2.5 & & 0.0 & 3.7 \\
Exoprts of G\&S & -3.0 & -14.1 & & 2.1 & 11.6 \\
Imports of G\&S & -9.5 & -33.3 & & -5.2 & 11.4 \\
\hline
\end{tabular}

- $\quad$ Staff had reservations about the June 2009 supplementary budget, which did not incorporate suggested improvements in the composition and size of adjustment. The budget also included about $1 \frac{1}{2}$ percent of GDP in savings from pension cuts, which were ultimately reversed by court decision. Fiscal performance criteria therefore allowed a higher deficit in the first year of the program than envisaged in the supplementary budget so that the most socially painful measures (such as such cuts to guaranteed minimum income) could be reversed and EUfinanced capital spending could be preserved. An adjustor on the fiscal deficit was introduced to safeguard social spending.

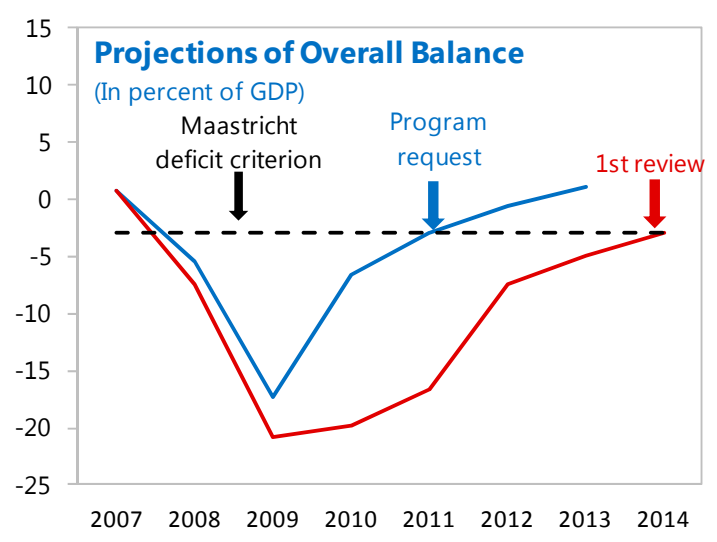

- $\quad$ Only a slight improvement in the fiscal balance was expected in the second year of the program with more rapid declines as the economy recovered.

\section{Despite these adjustments, significant risks to the program remained. Higher} deficits implied that more time may be needed to fulfill the Maastricht criteria and adopt the euro, public debt may be higher, and reaccessing international debt markets may be delayed.

\footnotetext{
${ }^{5}$ There was no explicit discussion of fiscal multipliers with the authorities and the EU, and that such considerations did not inform the design of the program given that the economic contraction had been primarily driven by the decline in private sector demand due to financing constraints.
} 
Combined with the difficulty of maintaining the peg and tenuous private sector confidence, there was therefore substantial risk of a prolonged need for official external support.

\section{Box 3. Latvia: The Decision to Maintain the Exchange Rate Peg}

The macroeconomic framework was centered on maintaining Latvia's exchange rate peg to the euro. An exchange rate adjustment would have had many advantages, notably, a quick correction of Latvia's real exchange rate misalignment, which staff had assessed to be significant in the 2008 Article IV consultation report. An exchange rate adjustment was initially considered a preferred option by many including in the Fund and outside observers, but there were considerable risks associated with it:

- A change in the peg was strongly opposed by the Latvian authorities and EU institutions, and thus was thought to pose risks to program ownership. The quasi-currency board regime had been an anchor of macroeconomic stability for more than 15 years, was able to withstand the 1998 Russian crisis, and commanded popular and political support.

- Devaluation would have created immediate large balance sheet effects, with a risk of negative feedback loops. Some 70 percent of bank deposits and nearly 90 percent of loans were foreign currency denominated at the time of the program request. Any change in the nominal exchange rate would have led to an immediate deterioration in private sector net worth.

- External financing needs might not have been significantly reduced. While devaluation would have decreased the current account deficit, private sector roll-over rates might not have improved, as the external debt-to-GDP ratio would have increased sharply.

- Given the fragile global funding environment at the time, the spillover risks may have been higher for other emerging European economies, especially in the Baltics and south-eastern Europe. Furthermore, loan losses in Nordic banks that invested in the Baltics could have hurt market confidence in these banks, which were already fragile because of their substantial dependence on wholesale financing.

Staff considered a number of alternative exchange rate options, but those were not supported by the authorities as well as regional partners. These included:

- Widening the exchange rate band to the full 15 percent range permitted under ERM2. Staff projected that this would improve competitiveness more quickly and eventually deliver a faster economic recovery, although growth would be depressed in the short run by balancesheet effects.

- Accelerated adoption of the euro at a depreciated exchange rate which could have provided a stable nominal anchor by removing currency risk.

${ }^{1}$ This box draws on the arguments presented in the program request staff report (IMF Country Report No. $09 / 3)$. 


\section{B. Adequacy of Financing}

24. In December 2008, the Fund approved a front-loaded and exceptional access SBA in the amount of SDR 1.52 billion (1,200 percent of quota and approximately $€ 1.7$ billion). Upon approval of the 27-month arrangement, SDR 0.54 billion (about 422 percent of quota) became immediately available. The total financing package was $€ 7.5$ billion, which included co-financing from the EU of $€ 3.1$ billion with $€ 2.2$ billion available in the first six months. It also included $€ 1.8$ billion from the Nordic countries expected to be available after the first year of the program. ${ }^{6}$ The remaining financing was provided by the Czech Republic, Poland, and Estonia ( $€ 0.4$ billion total) and the World Bank and EBRD $(€ 0.5$ billion total).

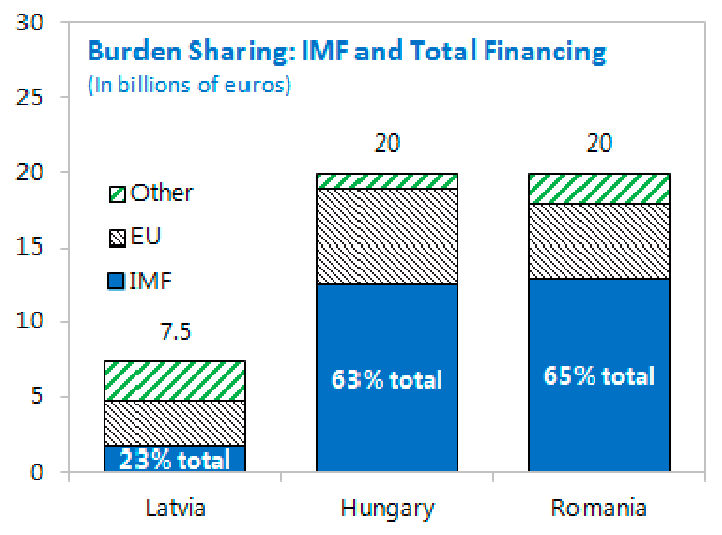

\section{The exceptional access request was justified by the large balance of payments}

needs over the program period. Although Latvia was experiencing a capital account crisis, it also had a large current account deficit at the time of the program request, which was expected to be closed only gradually especially given the decision to maintain the exchange rate peg. The pressures facing Latvia could have resulted in disorderly adjustment, including the unhinging of the fixed exchange rate regime, which would have had implications for neighboring countries with similar vulnerabilities. The front-loading of access reflected the upfront adjustment effort, and the need to quickly bolster foreign exchange reserves to restore confidence and financial sector stability. Fund exposure to Latvia was expected to peak at the end of the program at about 8 percent of GDP. To help mitigate associated risks, the program included strong up-front measures and its duration was set to encompass the passage of the budget for the first year following the program. Significant technical assistance to support reforms in the fiscal and banking sectors were envisaged and delivered during the program period.

\footnotetext{
${ }^{6}$ The Riksbank also provided a $€ 0.5$ billion swap line as bridge financing.
} 

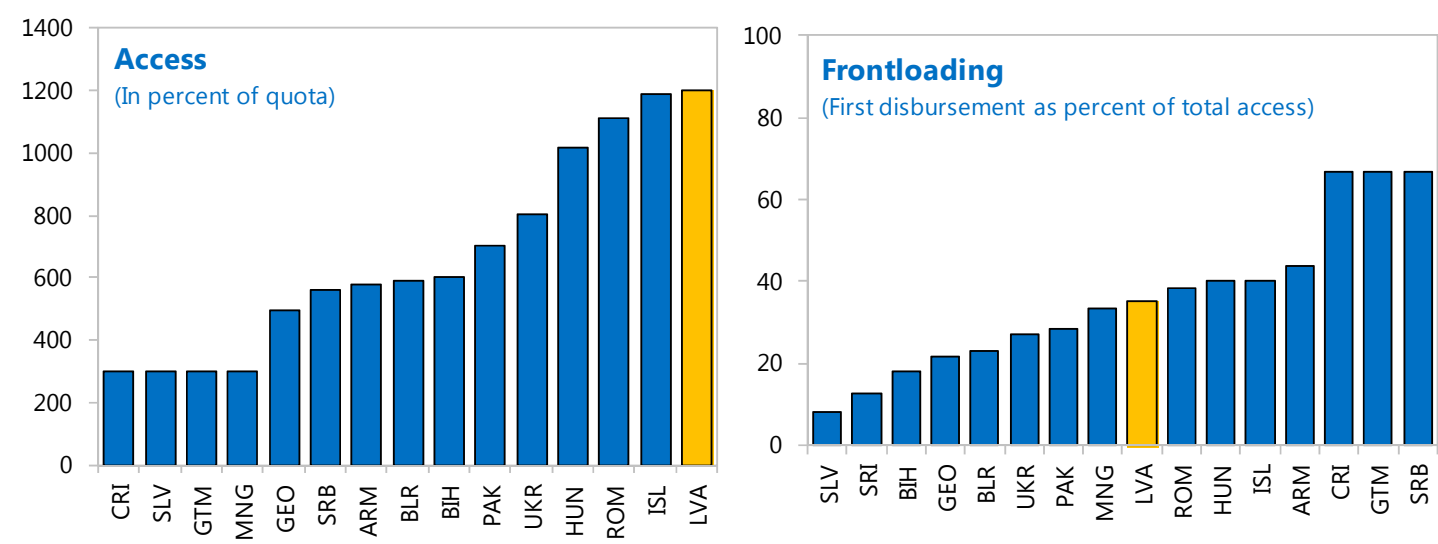

26. While in retrospect it appears that the program may have been over-financed, the confidence-enhancing effect of the large financing package is likely to have played a key role in arresting the crisis. Of the original $€ 7.5$ billion financing package, only $€ 4.5$ billion was drawn, including only $€ 1.1$ billion (SDR 0.98 billion) of the $€ 1.7$ billion available from the Fund. Latvia did not use any of the Nordic financing. Although it is difficult to explicitly account for the confidence boosting effects of a substantial financing package in helping to maintain external private sector exposure, the main reason for the significant reduction in financing needs was the unanticipated collapse in domestic demand and corresponding improvement in the current account balance, which was originally projected at -7.3 percent of GDP in the first year of the program but turned out to be +8.7 percent of GDP (see table in paragraph 46 ).

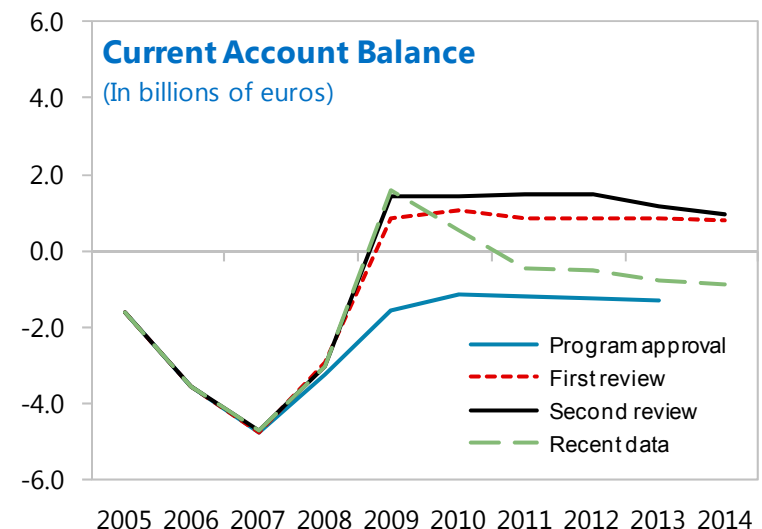

2005200620072008200920102011201220132014

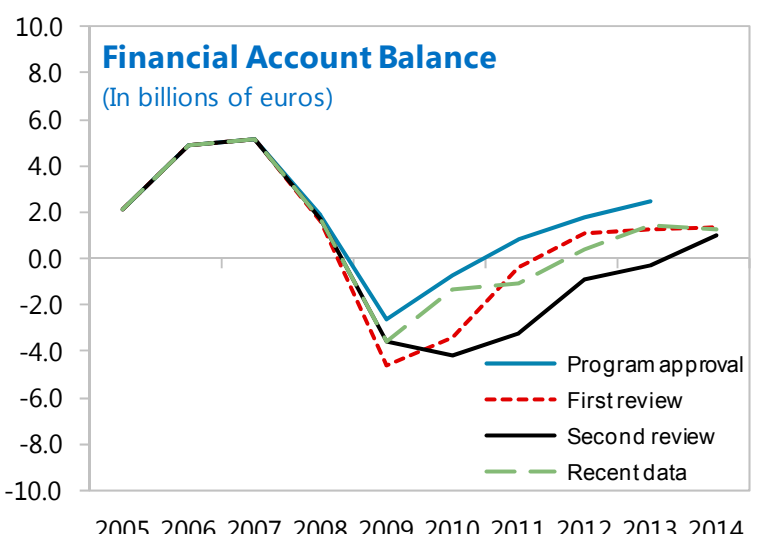

2005200620072008200920102011201220132014 


\section{Given fiscal pressures and absence of access to international markets, IMF} disbursements were used to support the budget. ${ }^{7}$ The government faced acute liquidity constraints because of the increasing fiscal deficit and the need to provide support to a systemically important bank (and potentially others) that could not be channeled through the Bank of Latvia. The initial disbursement was therefore used for general budget support. At the time of the first review it was decided to ring-fence resources for bank restructuring. In this regard, threequarters of Fund disbursements were used to address the balance of payments drains implied by the budget deficit while onequarter was segregated to ensure that there were sufficient reserves to cover fiscal costs of bank restructuring. Latvia's commitment

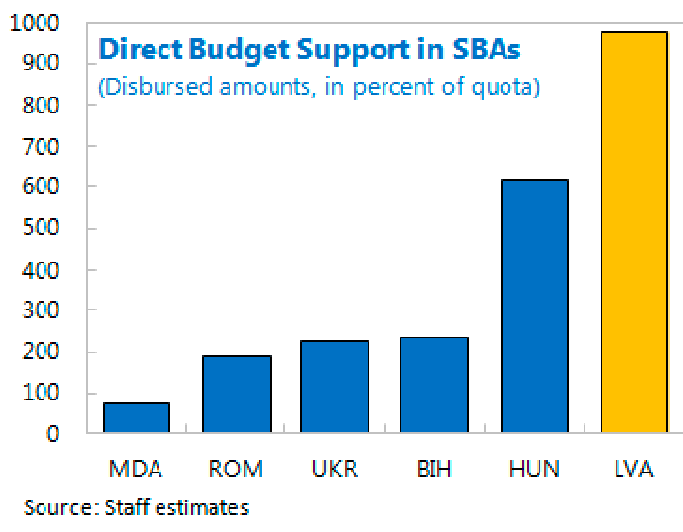
to the program, expected improvements in global financing conditions, and support from the EU were the primary safeguards.

\section{Exceptional Access Criteria}

\section{In line with the exceptional access policy at the time, the SBA request was} assessed in light of the exceptional access criteria. ${ }^{8}$ The assessment was broadly appropriate, although additional attention could have been given to the role of domestic factors in assessing prospects for regaining market access (criterion 3).

- $\quad$ Criterion 1: The member is experiencing exceptional balance of payments pressures on the capital account resulting in a need for Fund financing that cannot be met within the normal limits. Loss of confidence in the banking sector together with global deleveraging and few prospects for external finance resulted in large capital outflows, loss of reserves, and pressure on the currency. Absent exceptional financing from the Fund, there was a risk of a disorderly balance of payments adjustment. Although actual drawings were less than the approved 1,200 percent of quota, the large financing package likely had significant confidence-boosting effects. Latvia

\footnotetext{
${ }^{7}$ Because the treasury is the designated fiscal agent in Latvia (as opposed to the central bank), IMF disbursements were considered budget support, which is defined as the use of the domestic-currency equivalent of Fund disbursements to finance the budget while implementing a Fund-supported program aimed at resolving balance of payments difficulties.

${ }^{8}$ Since Latvia's program was approved before the Board decisions that modified exceptional access criteria (GRA Lending Toolkit and Conditionality-Reform Proposal, 3/19/2009), the request for exceptional access is assessed under the old criteria (PIN 03/37, 3/21/2003).
} 
drew a total of SDR 0.98 billion from the Fund, representing about 775 percent of original quota, well above the normal limits of 600 percent and justifying (ex-post) the exceptional access request.

- $\quad$ Criterion 2: A rigorous and systematic analysis indicates that there is a high probability that debt will remain sustainable. Public debt was very low and expected to remain sustainable, increasing in the near-term with new borrowing under the program before declining in the medium term. The much heavier external debt burden was mostly concentrated in the private sector with a significant share owed to affiliated banks and companies of foreign enterprises operating in Latvia. The low public debt level provided room for the government to absorb some (foreign and domestic) private liabilities without unduly undermining fiscal sustainability.

Projected debt ratios deteriorated at the first two reviews, largely as a result of the unanticipated collapse in domestic demand. In later years, the outlook improved as Latvia decided not to draw on the full financing package.
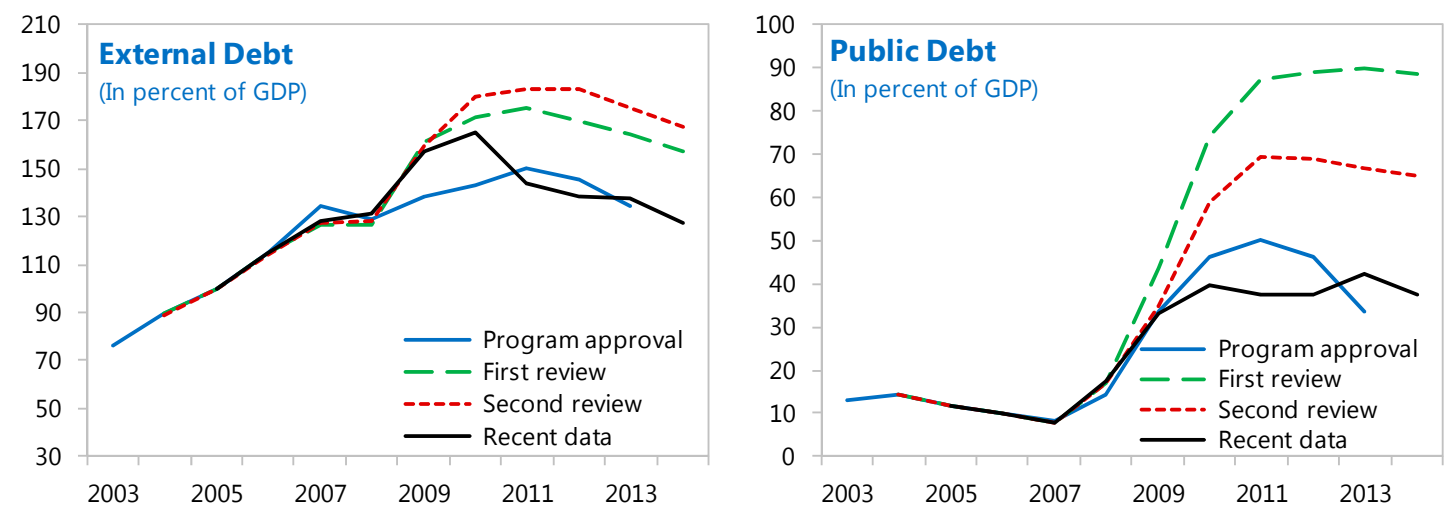

Criterion 3: The member has good prospects of regaining market access within the time frame that Fund resources would be outstanding. In staff's view, Latvia's access to private financial markets was likely to be restored, particularly if international financial markets normalize, or if it would be able to join the Euro area. Specifically, the program assumed market access would be restored in 2011. This assessment was based on the premise that loss of market access was linked to global developments and domestic banking problems exacerbated the loss of confidence. It is arguable whether this premise should have been sufficient. Domestic factors, namely the buildup of vulnerabilities associated with the overheating economy and its reliance on non-resident financing underlied much of the confidence loss in Latvia.

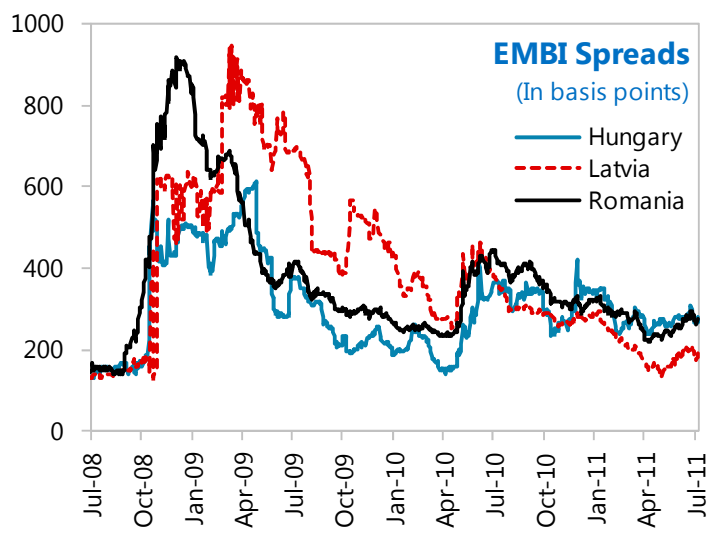


Nevertheless, since mid-2011 Latvia has made 3 international bond issuances including the 7-year Eurobond issued in December 2012 which raised $\$ 1.25$ billion at a low yield of 2.9 percent.

- $\quad$ Criterion 4: The policy program of the member provides a reasonably strong prospect of success, including not only the member's adjustment plan but also its institutional and political capacity to deliver that adjustment. The program was supported at the highest political level, with cross-party support for maintaining the peg. After program approval, political uncertainty increased with the resignation of the Prime Minister and the governing coalition being blamed for Latvia's economic difficulties. The situation then stabilized following municipal and European elections. The LOI for the first review was signed by the new Prime Minister and Finance Minister, the Central Bank Governor, and members of the coalition parties.

\section{A reassessment of exceptional access criteria was not conducted at subsequent} reviews. Although not explicitly required under the exceptional access policies, in practice if a reassessment is not conducted with subsequent reviews, it implicitly indicates that there is no change in staff's assessment. Given the significant changes to program design and the macroeconomic outlook at the time of the first review, an update of the assessment would have been beneficial.

\section{There was an appropriate level of Board consultation in the lead up to the SBA} request. Emergency procedures were activated at the informal Board session on November 17, 2008 and an additional informal Board briefing was held on December 5 to update the Board on technical discussions between staff and the authorities on the design of a program. A report assessing the needs for an SBA involving exceptional access was discussed on December 10, consistent with exceptional access procedures.

\section{Appropriateness of Conditionality}

\section{Program conditionality appropriately aimed to arrest the immediate liquidity} crisis and then ensure long-term external stability. Structural measures were therefore concentrated in the financial and fiscal sectors (Table 1). Quantitative performance criteria were streamlined and included the standard targets on net international reserves, net domestic assets, and the fiscal balance and were updated at each review to reflect revisions to the macroeconomic outlook and lock-in overperformance particularly in the fiscal area (Table 2). There was also an indicative target on the wage bill, which was a key feature of the internal devaluation strategy.

\section{The number of structural conditions was larger than in comparator programs.}

Structural reforms were particularly critical to improve competitiveness in the context of the fixed exchange rate regime. The concentration of structural measures in the financial and fiscal sectors also reflected the severity of the problems in these sectors. Many of the 
benchmarks laid out intermediate steps toward an end goal, which may have helped to preserve reform momentum and ensure the sustainability of adjustment. Nonetheless, given the strength of program ownership especially in the fiscal sector, a reduction in the number of intermediate measures may have been possible.

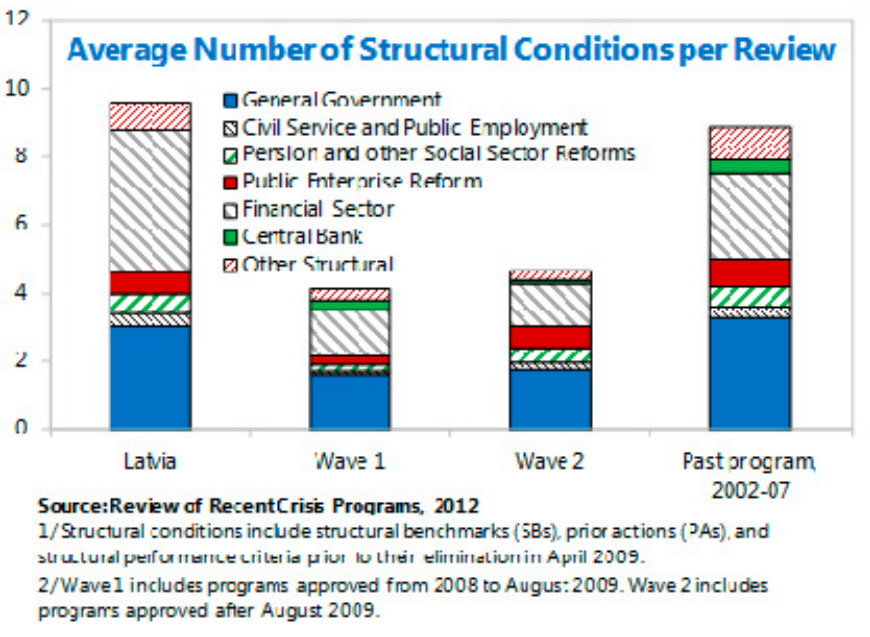

33. Conditionality to stabilize the financial sector relied on a prior action and many structural benchmarks. In addition to the prior action on Parex Bank, the program request included four benchmarks aimed at restoring confidence and reducing vulnerabilities in the rest of the banking sector. Subsequent reviews added 16 additional benchmarks primarily aimed at progressing bank resolution and bolstering stability. As indicated above, financial sector conditionality could have been streamlined by focusing on essential benchmarks (for example, regarding the restructuring of the state-owned Mortgage and Land Bank where solvency concerns emerged) and dropping others (for example, the call for international assistance in improving the stress testing framework).

\section{Conditionality also aimed at strengthening fundamentals for a sound longer-} term performance. In particular, the authorities agreed to strengthen crisis management capacities in line with the recommendations of the 2007 FSAP. The program also aimed to improve debt restructuring policies and procedures, which included amendments to the insolvency law facilitating loan work out between viable corporates and their creditors, improvements of the personal bankruptcy framework to effectively address individual insolvencies, and consideration to set up an asset management company.

\section{Conditionality in the fiscal sector relied on a combination of prior actions,} structural benchmarks, and quantitative performance criteria. The first prior action initiated the strong up-front fiscal consolidation with the adoption of a supplementary budget for 2009 by Parliament. The second prior action further cemented fiscal tightening and initiated the real devaluation with a protocol stipulating a public wage reduction. The program also included structural conditions aimed at improving fiscal sustainability. Given the strength of program ownership and regular overperformance on quantitative fiscal targets, there may have been scope to reduce the number of structural conditions in the fiscal sector. 


\section{PROGRAM IMPLEMENTATION}

36. The program was successful in arresting the immediate liquidity crisis and improving long-term external stability under the peg. The large and front-loaded financing package and immediate measures to stabilize the financial sector helped to bolster foreign exchange reserves, restore depositor confidence, and stem capital outflows. The sharp demand contraction that followed the sudden stop led to a large adjustment in the current account, which

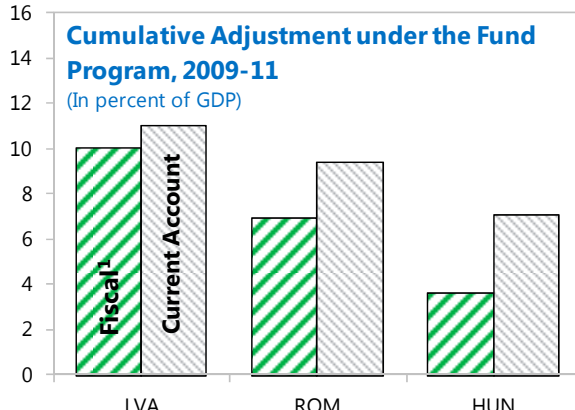

$1 /$ The difference between the change in the primary balance and automatic stabilizers. was key to restoring external sustainability.

Measures to foster real depreciation, including through significant fiscal tightening and wage restraint also played a role in improving competitiveness.

\section{Program performance was initially mixed, but subsequently improved}

considerably. The new government formed in early 2009 showed strong commitment to the reform strategy and advanced deep frontloaded fiscal adjustment starting in mid-2009. The vast majority of structural benchmarks were met, although many with significant delay.

\section{Internal adjustment supported a significant narrowing of the competitiveness}

gap. The economic slack along with internal devaluation policies, primarily wage restraint and structural reforms, contributed to a significant real effective exchange rate depreciation during the course of the program. Recent estimates of the real exchange rate in the 2012 Article IV report indicate that it is broadly in line with fundamentals with only a modest competitiveness gap remaining. However, labor relocation from the nontradable to tradable sector is still ongoing and unemployment is likely to remain high for some time (Box 3).

\section{Program delays stemmed largely from election cycles and corresponding need} for additional time to identify fiscal measures. In particular, the first review was delayed by six months mainly as a result of the change of government in early 2009 , local elections in mid-2009, and the resulting additional time needed to identify specific measures to support the planned adjustment. In the interim, the EU moved unilaterally to disburse its next large tranche of financing. This may have reduced the Fund's ability to convince the authorities of the merit of its preferred measures, resulting in what some staff considered a suboptimal 
fiscal program. ${ }^{9}$ Ultimately, strong program ownership of the large fiscal adjustment ensured the program's objectives were met. The fourth review was also delayed by six months as a result of the October 2010 elections and identification of 2011 fiscal measures.

\section{Box 4. Latvia: Internal Devaluation}

Internal devaluation policies aimed at improving competitiveness through wage cuts in the government and state-owned enterprises, promotion of wage restraint in the private sector, (e.g., via actions by a new Committee to Promote Wage Restraint created within the National Tripartite Cooperation Council), and structural measures to improve the ease of doing business and productivity.

These policies along with significant economic slack helped factor prices decline relative to trading partners. The real effective exchange rate depreciated as wages and prices declined. Notably, the ULC-based real effective exchange

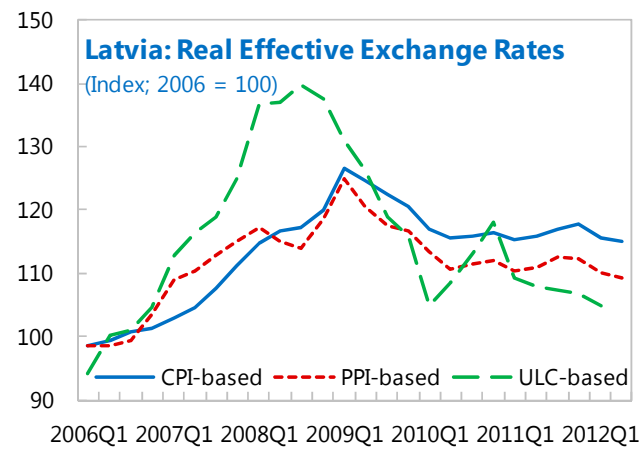
rate depreciated by about 24 percent from the peak in mid 2008 to end-2011. The CPI- and PPI-based REER depreciated by about 7 and 10 percent respectively from their peaks till end 2011. According to staff latest estimates (in the 2012 Article IV consultation staff report) the real exchange rate is broadly in line with fundamentals with calculations indicating that only a modest competitiveness gap remains.

From the peak at the height of the crisis in end-2008 to trough at early 2010 , public wages fell by 27 percent while private wages fell by 6 percent and started growing again in mid 2010 (although anecdotal evidence suggests that the true private wage decline is larger). Much of the adjustment to the drop in demand was achieved through layoffs rather than wage reduction. Unemployment rose even as emigration increased (about 4 percent of the population emigrated during 20082010). Job losses were concentrated in the non-tradable sector, notably construction, where roughly a third of all job losses took place.

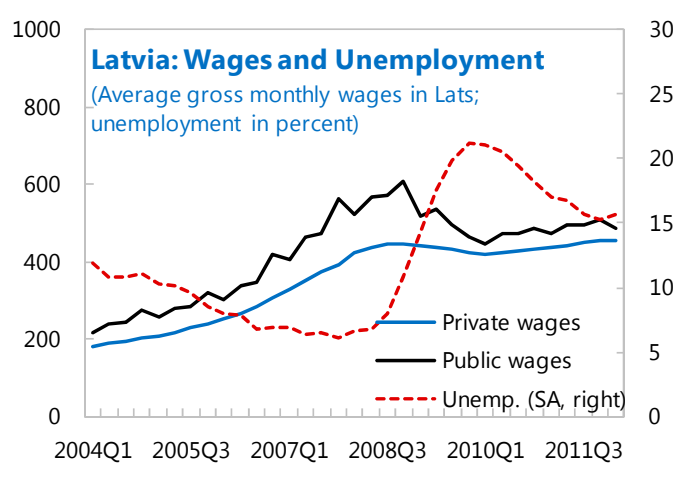

Sources: National authorities; and IMF staff estimates

The unemployment rate is now declining rapidly despite increasing participation in the labor market, underpinned by strong job creation. Nonetheless the level of unemployment - mainly structural unemployment - remains high, suggesting mismatches in the labor market that will likely take time to unwind.

\footnotetext{
${ }^{9}$ In the period leading to the first review there was a difference of views between the IMF and the European partners on the adequacy of fiscal measures underlying the 2009 supplementary budget. This led to perceptions of a rift between the IMF and the EC. This issue is elaborated in How Latvia Came through the Financial Crisis by Anders Åslund and Valdis Dombrovskis (pages 85-88). Subsequent reviews were conducted in coordination with the EC.
} 


\section{A. Macroeconomic Projections}

40. The economic downturn proved to be much deeper than expected (Figure 4). The initial program forecast of an economic contraction of 5 percent in 2009, while more conservative than consensus forecast, proved too optimistic as the outturn was a decline of about 18 percent. The forecast was built on the assumption that, under the peg the adjustment would be sluggish as sticky prices and wages take time to adjust. A recovery was expected to follow as internal adjustment policies would support a gradual shift in relative prices, which would promote external competitiveness and export-driven growth.

\section{The collapse in private domestic demand and exports was severe, but the} recovery also exceeded expectations. Export demand declined significantly due to an unfavorable external environment and the impact of strained financial conditions on domestic demand and imports proved to be much stronger than anticipated. This led to a correction in the trade balance ahead of any noticeable change in relative prices. The sharp initial decline in demand was followed by a rather quick output stabilization and trade balance adjustment, which was more akin to the shape of adjustment anticipated under the devaluation scenario considered by staff, although significantly larger in magnitude. GDP bottomed out in the third quarter of 2009 and grew in the last quarter 2009 (seasonally adjusted), one year sooner than originally forecast.

Expectations at the Request for SBA (December 2008)
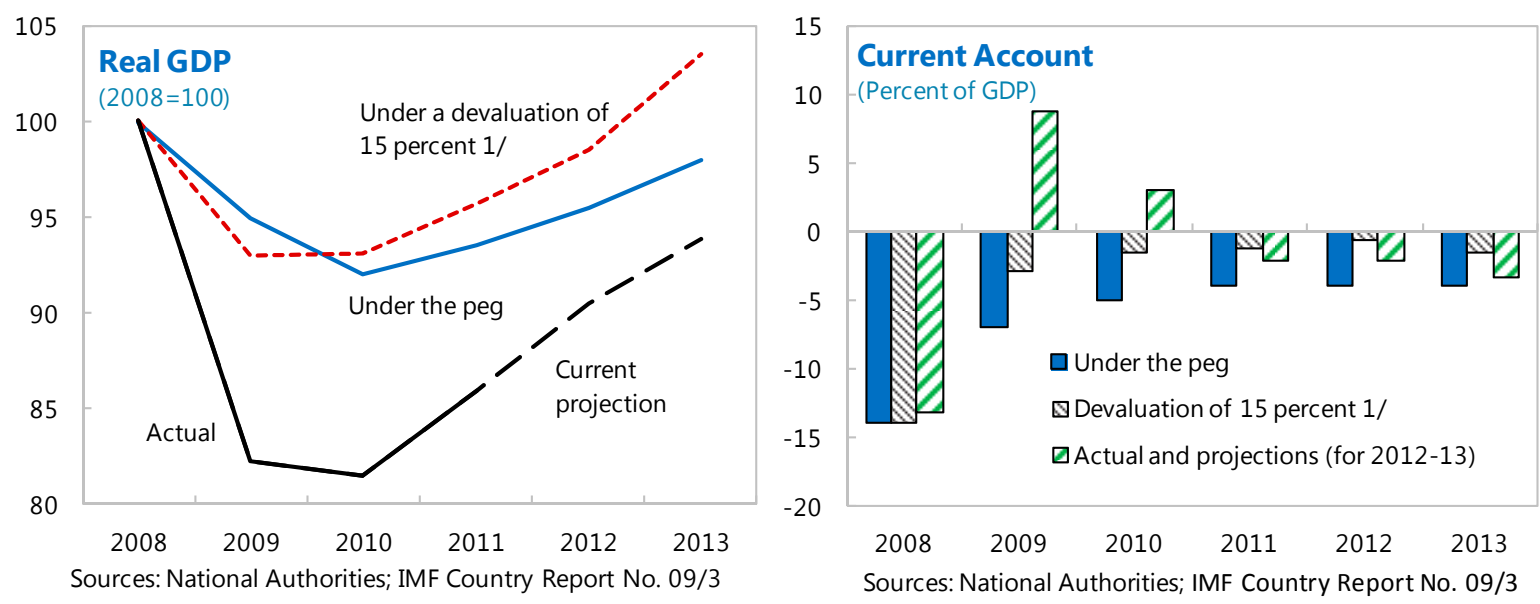

1/ Under the ERM2, widening the exchange rate band by the maximum allowed could depreciate the Lats by at most 15 percent.

42. Uncertainty regarding program implementation and rumors concerning the sustainability of the peg led to continued pressures on reserves and capital outflows until mid 2009. Despite the initial disbursements by the IMF (about $€ 591.5$ million in December 2008) and EU ( $€ 1$ billion in February 2009) pressure on reserves continued. From 
January to June 2009, banks reduced their external debt by about $€ 2.3$ billion while the net stock of foreign reserves declined by $€ 1.7$ billion ( $2 / 3$ of total) dipping below $€ 1$ billion. This fast decline triggered the consultation clause on reserves. Headwinds from the severe international liquidity squeeze compounded Latvia-specific concerns.

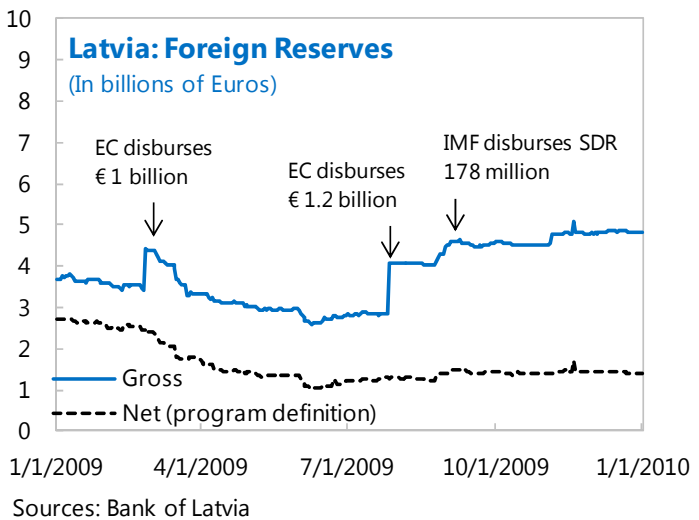

\section{Concerns over the health of the banking sector also continued until the third} quarter of 2009. The system-wide nonperforming loan ratio rose to 16 percent by end-2009, which led to a sharp drop in profitability (return on equity was -42 percent). The worse-thanexpected macroeconomic and bank performance led to several episodes of intensified pressures on bank deposits, as well as weak confidence in the lats.

\section{The summer of $\mathbf{2 0 0 9}$ marked a turnaround in market confidence. Market} pressures eased following disbursements of EU funds ( $€ 1.2$ billion) in July which was followed shortly by the completion of the first review under the SBA in August ( $€ 195$ million). The renewed commitment by the government for frontloaded adjustment along with significant correction in the current account helped ease reserve pressures. At the same time, the liquidity squeeze in international markets eased as the global external environment improved. Foreign reserves and bank deposits stabilized and the interbank rates returned to single digits. By end-2011, the current account balance was in a slight deficit (after registering surpluses in 2009 and 2010), the fiscal deficit improved to 3.1 percent of GDP, and output grew by 5.5 percent.

45. Performance in the banking sector began to improve in 2010 (Figure 5 and 6). Capital adequacy and other banking sector soundness indicators (credit quality and profitability) began to improve in 2010 . The size of the Latvian banking sector contracted substantially during the program period. From its peak of L23.2 billion in December 2008 (144 percent of GDP), bank assets gradually decreased to L19.9 billion in June 2012 (130 percent of GDP).

\section{Bank recapitalization costs turned out to be much lower than originally}

estimated. Under conservative assumptions regarding parent support for foreign banks, bank recapitalization using public funds for 2009 and 2010 was originally estimated at $€ 2,110$ million (17 percent of GDP). This turned out to be substantially higher than the actual recapitalization of $€ 1,320$ million (10 percent of GDP), of which around one half came from the private sector, mainly from the foreign parent banks. 
Latvia: Balance of Payments, 2008-11

(Percent of GDP)

\begin{tabular}{|c|c|c|c|c|c|c|c|c|}
\hline & \multicolumn{2}{|c|}{2008} & \multicolumn{2}{|c|}{2009} & \multicolumn{2}{|c|}{2010} & \multicolumn{2}{|c|}{2011} \\
\hline & $\begin{array}{r}\text { SBA } \\
\text { request }\end{array}$ & Actual & $\begin{array}{r}\text { SBA } \\
\text { request }\end{array}$ & Actual & $\begin{array}{r}\text { SBA } \\
\text { request }\end{array}$ & Actual & $\begin{array}{r}\text { SBA } \\
\text { request }\end{array}$ & Actual \\
\hline Current account & -14.9 & -13.2 & -7.3 & 8.7 & -5.5 & 3.0 & -5.4 & -2.1 \\
\hline Capital and financial account & 10.2 & 10.5 & -10.1 & -18.4 & -0.4 & -5.6 & 6.8 & -2.4 \\
\hline Capital account & 1.5 & 1.5 & 1.9 & 2.4 & 2.9 & 1.9 & 3.1 & 2.1 \\
\hline Financial account & 8.7 & 9.0 & -12.1 & -20.9 & -3.3 & -7.5 & 3.6 & -4.5 \\
\hline Direct investment & 4.9 & 3.1 & 1.1 & 0.6 & 3.8 & 1.5 & 4.6 & 4.9 \\
\hline Portfolio investment & 1.2 & 1.1 & -1.4 & 0.7 & -1.4 & -0.9 & -0.7 & -2.2 \\
\hline Financial derivatives & 0.5 & -0.3 & 0.5 & 1.6 & 0.5 & -0.9 & 0.5 & 0.4 \\
\hline Other investment & 2.1 & 5.1 & -12.3 & -23.8 & -6.2 & -7.2 & -0.8 & -7.6 \\
\hline Of which: non-resident deposits & -5.0 & -3.3 & -5.4 & -0.8 & -2.4 & 3.7 & -0.3 & 2.4 \\
\hline Errors and omissions & -1.5 & -1.8 & 0.0 & 0.8 & 0.0 & 0.5 & 0.0 & -0.3 \\
\hline Overall balance & -6.2 & -4.6 & -17.4 & -9.0 & -5.9 & -2.1 & 1.3 & -4.9 \\
\hline Financing & 6.2 & 4.6 & 17.4 & 9.0 & 5.9 & 2.1 & -1.3 & 4.9 \\
\hline Reserve assets (increase:-) & 1.1 & 2.0 & 1.6 & -5.0 & -6.4 & -4.0 & -3.2 & 4.4 \\
\hline IMF (net) & 2.8 & 2.6 & 2.8 & 1.0 & 1.9 & 1.7 & 0.5 & 0.0 \\
\hline Other exceptional financing & 2.3 & 0.0 & 13.1 & 12.9 & 10.4 & 4.4 & 1.4 & 0.5 \\
\hline \multicolumn{9}{|l|}{ Memorandum item: } \\
\hline Nominal GDP (Millions of euros) & 21,577 & 22,731 & 21,432 & 18,563 & 21,165 & 18,162 & 21,639 & 20,469 \\
\hline
\end{tabular}

Sources: Latvian authorities and IMF staff estimates.

\section{B. Fiscal Policy}

47. The initial implementation of the fiscal program was weak and the fiscal targets set at the SBA inception were missed. The floor on adjusted cash fiscal balance and the ceiling for the wage bill for December 2008 and March 2009 and the indicative target for June 2009 were breached. The program's fiscal measures were only partly implemented, the wage bill exceeded program targets, and revenues collapsed with private demand. Due to across-the-board cuts in spending, domestic arrears accumulated in early 2009. During this period the government fell and a new cabinet was formed in March 2009.

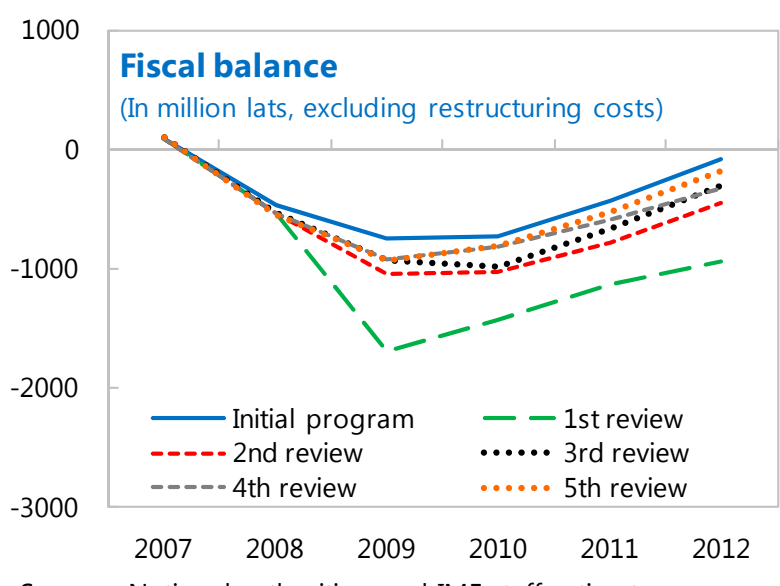

Sources: National authorities; and IMF staff estimates

\section{Following the first review, implementation of fiscal policy strengthened}

considerably. While fiscal targets were relaxed, the authorities implemented deeper budget cuts and the actual fiscal balance remained above the established floors for the rest of the program. The fast adjustment path adopted by the authorities was consistent with commitments with the EC to reach the Maastricht criterion by 2012. Public wages were reduced substantially, notably for teachers, and expenditures in health, education, defense, interior and agriculture were cut down. No immediate offset to the reversal of the pension 
cuts was taken given the political pressures and the otherwise strong program implementation..$^{10}$ The momentum for adjustment continued into 2010 as the budget approved in late 2009 included significant net new savings (equivalent to 4.2 percent of GDP). The 2011 budget and its supplement implemented an additional 2.6 percent of GDP in adjustment measures - mainly on the revenue side - and by end-2011 the fiscal deficit was reduced to -3.1 percent of GDP (program methodology).

49. While the size of the adjustment was large and exceeded expectations, staff had concerns about the quality, composition, and sustainability of the adjustment measures. The room under the program for higher social spending was not fully used although safety net schemes, including public works program, were put in place. In addition, staff had concerns regarding a number of issues including:

- $\quad$ the cuts in health, education, and co-financing of EU-funded projects;

- the regressive nature of the (initial) reduction of pensions, central transfers for the guaranteed minimum income payments, and the personal income tax allowance;

- $\quad$ the increase of dividends from SOEs, including from the central bank; and

- $\quad$ the need for some pension cuts following the constitutional court ruling that overturned the initial cuts. Pension payments reached around 20 percent of total public spending in 2010 (or about 9.8 percent of GDP).

50. Despite these concerns staff recommended completion of program reviews at critical junctures largely in recognition of the authorities' determination to meet the program fiscal objectives and the support of partners. This was particularly evident at the time of the first review when two scenarios were presented in the staff report showing two different paths for fiscal adjustment. Staff analysis showed that debt would remain sustainable under the authorities' fast adjustment scenario as well as a scenario of slower and more gradual adjustment, which provided assurances for the Fund to complete the first review.

\section{Financial Sector}

\section{Commitments from parent banks played a key role in stabilizing the financial} sector. Parents of the largest Nordic banks had periodic meetings, which resulted in repeated reassurances to maintain the overall exposure levels to Latvia. ${ }^{11}$ The reduction in foreign

\footnotetext{
${ }^{10}$ Instead, a new structural benchmark was added to readdress pension reform consistent with the constitution. Ultimately, no substantive action was taken to reform the pension system.

${ }^{11}$ Close cooperation between the IMF team and the supervisory authorities and Ministry of Finance of Sweden was also very helpful. Cross-border cooperation with parents banks' supervisors intensified through participation in supervisory colleges. Several group-specific memoranda of understanding on information exchange were signed, and the Nordic-Baltic Agreement on cooperation on cross-border financial stability, crisis management and resolution was adopted in late 2009.
} 
banks' liabilities to their parents, in an environment of global deleveraging, was done in a gradual manner which helped preserve stability. Nordic banks converted part of liabilities into subordinated loans, which increased capitalization but decreased liabilities to parent banks.

\section{The resolution of Parex bank, particularly the restructuring of syndicated loans,} proved to be challenging. The bank lost access to wholesale funding and did not have enough own resources to repay large syndicated loans maturing in early 2009. These loans had "material adverse clauses" in their agreements, which accelerated full repayment of all syndicated loans based on certain parameters (e.g., falling below certain capital requirements, failing to make payment on time). Following protracted and difficult negotiations, the syndicates agreed to only marginally extend the maturities of some loans. Of the $€ 775$ million of syndicated loans, Parex's external creditors were paid €232 million in March 2009. The extension of maturity of the remaining amount was only to 2011, which implied a lower roll-over rate than envisaged under the original program. ${ }^{12}$ While the sums involved were modest relative to total public debt, the pros and cons of restructuring the loans were debated, and the authorities decided to fully repay them primarily to avoid undermining market perceptions of Latvia.

\section{The authorities took important steps to strengthen the bank resolution} framework with the support of technical assistance from the IMF. The regulations on emergency liquidity support of December 2008 broadened the range of eligible collateral with safeguards for stricter supervisory oversight. Legal amendments of February 2009 enhanced the powers of the FCMC in replacing bank managers and board members with a temporary administrator without a court approval and authorized purchase and assumption transactions for banks without the consent of transferred creditors. The deposit insurance fund was transformed into an autonomous unit of the FCMC in early 2010, and its funding arrangements were improved.

54. These measures helped the authorities proceed with the resolution of two large problem banks - Parex and Mortgage and Land Bank (MLB) - broadly in line with the agreements with the Fund and EC. The resolution of Parex involved the establishment of a good-bad bank structure: good assets and liabilities were transferred to a newly created entity (Citadele), while Parex bank became in charge of managing old bad assets. The plans to sell Citadele have not yet materialized due to the lack of interest from potential buyers. ${ }^{13}$ The

\footnotetext{
${ }^{12}$ The government guarantee was provided on the restructured syndicated loans. The first tranche was repaid with state liquidity support whereas afterwards it was progressively from the bank own resources. By the time of the fourth review in May 2011, all these loans were repaid.

${ }^{13}$ The restrictions on deposit withdrawals in late 2008 were softened during 2009-11 and eventually removed in January 2012.
} 
resolution of MLB involved the creation of a company to manage its bad assets (Hiponia) and a subsequent bundling and auctioning of assets and liabilities. The process of resolving MLB encountered significant delays due to the absence of political consensus.

\section{Major efforts were made to improve the private debt restructuring framework.}

Amendments to the Civil Law made the seizure of collateral a credible threat, the foreclosure auction requirements were streamlined, regulations were introduced to reduce tax disincentives for debt write-downs, and a new personal insolvency law was introduced. These measures allowed banks to enhance workout of loans to problem borrowers. The improvements, as well as the impact of the downturn itself, led to a sharp increase in legal protection and personal insolvency proceedings. For example, the number of personal insolvency proceedings increased to 245 cases filed with the court from August 2009 to June 2010 , compared to only 57 cases in the 18 months prior to that.

\section{Monetary and Exchange Rate Policy}

56. Monetary policy has been appropriately anchored by the fixed exchange rate regime and coordination between the ministry of finance and the BoL generally improved during the program. Staff rightly argued at various times during the program for a more activist stance within the confines of the peg to better manage domestic liquidity and contain potential pressures on reserves. This included calls for actively managing excess liquidity, including through adjustment in official interest rates and better coordination between the Treasury and the BoL. On the latter, the domestic issuance of Treasuries in the spring 2009 temporarily helped absorb liquidity but an undersubscribed auction in June caused an interest rate spike and contributed to reserve pressures. This issue was addressed at the time of the first review; the Treasury would only sell foreign currency directly to the $\mathrm{BoL}$ which would actively mop up liquidity as needed. These measures helped keep the Lats close to the upper bound of the range. From 2011, the Treasury started to pre-announce its auctions of foreign currency, which would be limited to its

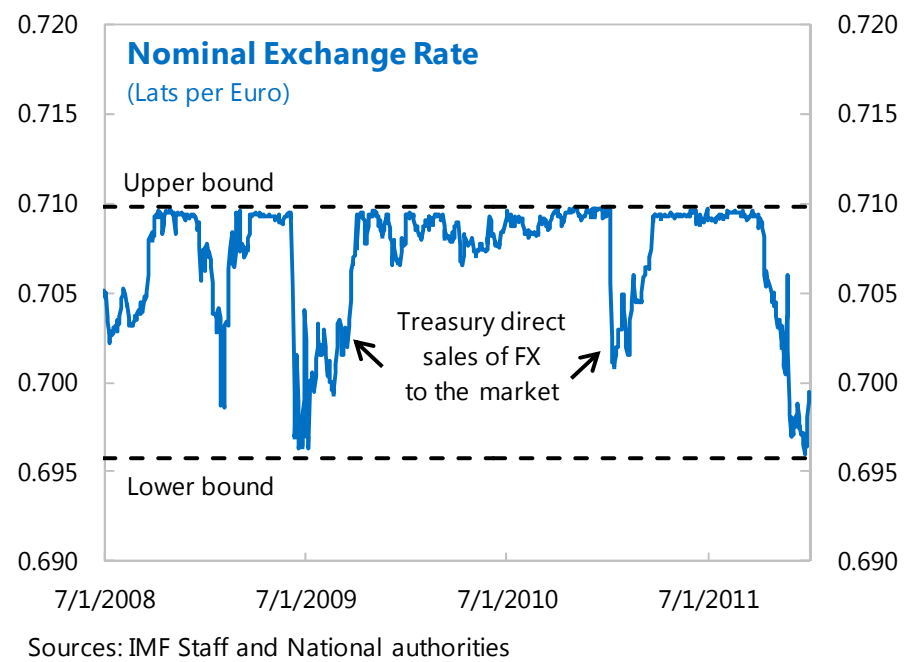
financing needs. 


\section{CONCLUSIONS AND LESSONS}

57. The 2008 crisis had a deep impact on the Latvian economy. The crisis had its roots in a boom-bust cycle that was amplified by unusually high credit growth financed with large capital inflows, which fueled a large current account deficit and the buildup of significant financial sector vulnerabilities. The bursting of the bubble led to an overall decline in GDP of about 25 percent - the sharpest output decline in the current global crisis. This drop, along with pre-crisis procyclical fiscal stance and bank restructuring costs led to serious strains on the government fiscal accounts.

58. The Latvia program, supported by the Fund and other partners, was instrumental in restoring confidence in the financial sector, and containing the impact of the crisis. In fact, Latvia made major strides in improving its macro fundamentals during the program. While delayed, the program exit strategy is well within reach now.

59. Further efforts however are still needed to consolidate the gains made in the past two years. In particular:

- $\quad$ The level of GDP is still below potential and unemployment is very high. Structural policies should continue with a view to ensuring that competitiveness continues to improve and unemployment is significantly reduced, including through reductions in the high NAIRU (non-accelerating inflation rate of unemployment).

- $\quad$ Additional effort is needed to further cement fiscal discipline. Latvia has ratified the EU's Fiscal Compact and enacted the domestic legislation making it binding domestically. It is expected that the Fiscal Discipline Law will be considered by Parliament in early 2013.

- Reliance of banks on external financing is again on the rise after a temporary drop in 2008-09. Deposits from non-residents account now for more than half of the total deposits in the banking sector. In addition to building adequate buffers, regulatory and supervisory vigilance is needed to limit the associated vulnerabilities.

60. A number of key lessons could be drawn from the experience of Latvia.

- $\quad$ Strong ownership is critical to successful adjustment and reform. Strong ownership in Latvia was rooted in general public acceptance of difficult austerity measures, which was essential in facilitating frontloaded fiscal adjustment.

- $\quad$ Strong support by the international community was instrumental in arresting the confidence crisis and in further buttressing national ownership. The international community supported the adjustment program with a large and coordinated financing package including commitment from a large number of regional partners and neighboring countries. 
- $\quad$ Effective engagement by the private sector was critical to help support confidence in the banking sector. In particular, commitment and action by parent banks to maintain their exposures in Latvia, and to capitalize their subsidiaries helped restore the viability of the sector and limit the need for public support to banks.

- $\quad$ Under the specific conditions prevailing in Latvia, the internal adjustment helped achieve external stability. These conditions included low initial public debt, strong ownership that allowed for large upfront fiscal adjustment to bolster confidence before fatigue set in, and a large upfront current account adjustment which helped restore external imbalances even before the impact of fiscal adjustment materialized. Internal devaluation policies helped support relative price adjustment including in the labor market, where wages experienced some nominal decline. It should be underlined that these conditions may not be easily replicable in other countries. Furthermore, the remaining high unemployment and output that is still below precrisis levels point to the rather lengthy character of the ongoing adjustment.

- $\quad$ Real-financial linkages play a major role in propagating the impact of shocks. In the case of Latvia, the underestimation of these linkages led to an underestimation of the impact of the financial crisis on real activity and thus an unduly tight fiscal stance at program inception, which was subsequently revised.

- $\quad$ Flexibility in program design helped ensure the program achieved its objectives. Program design, particularly in the fiscal area, effectively adapted to evidence of a sharper than projected output collapse.

- An explicit and credible exit strategy can help to boost confidence and anchor program objectives. At the time of program approval, the exit strategy of euro adoption was seen as a credible means to reduce vulnerability to financial and balance of payments crises including because of the authorities strong commitment. 
Figure 1. Selected Indicators, 2003-08

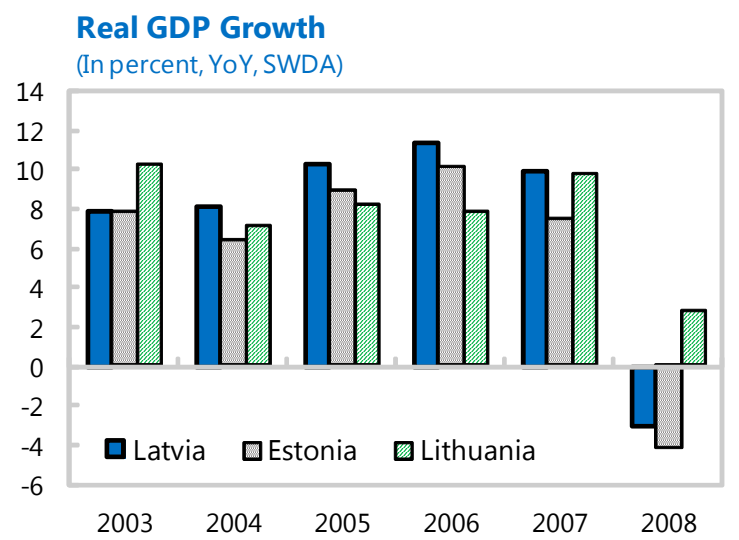

Sources: Haver; and IMF staff calculations

Bank Funding

(In billion lats)

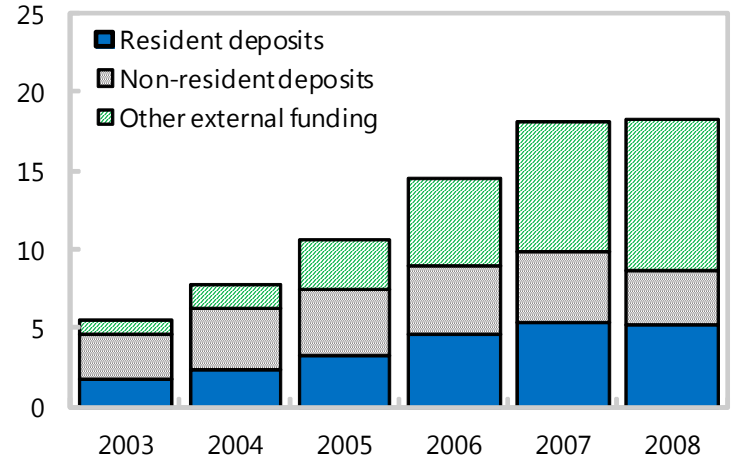

Sources: Bank of Latvia

\section{Credit to Private Sector}

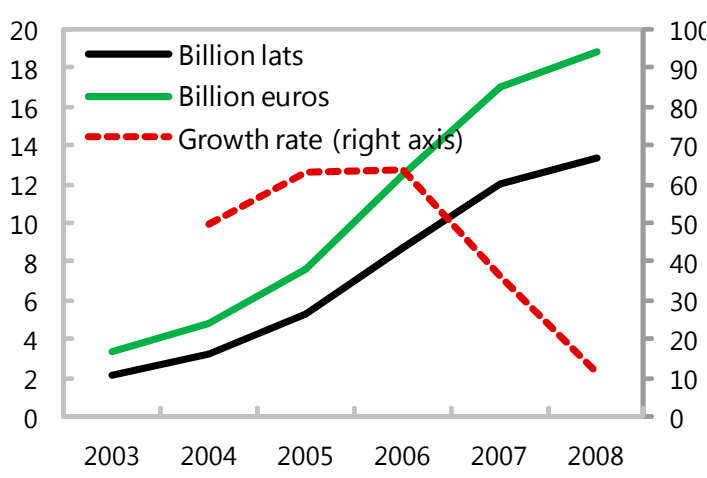

Sources: Bank of Latvia

Real Estate Prices

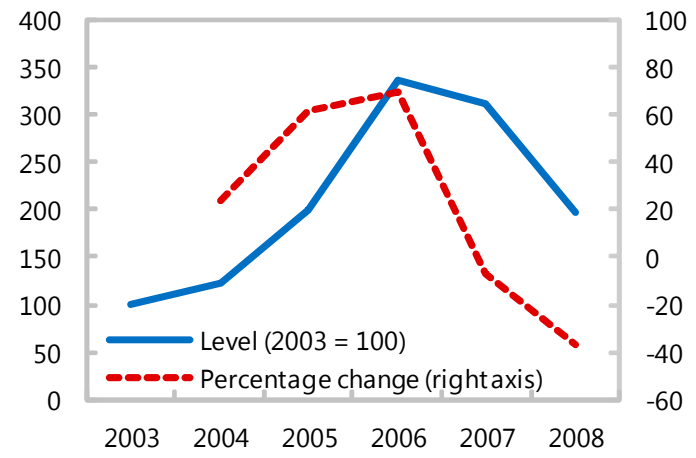

Sources: National authorities.

\section{Fiscal Indicators 1/}

(In billion lats)

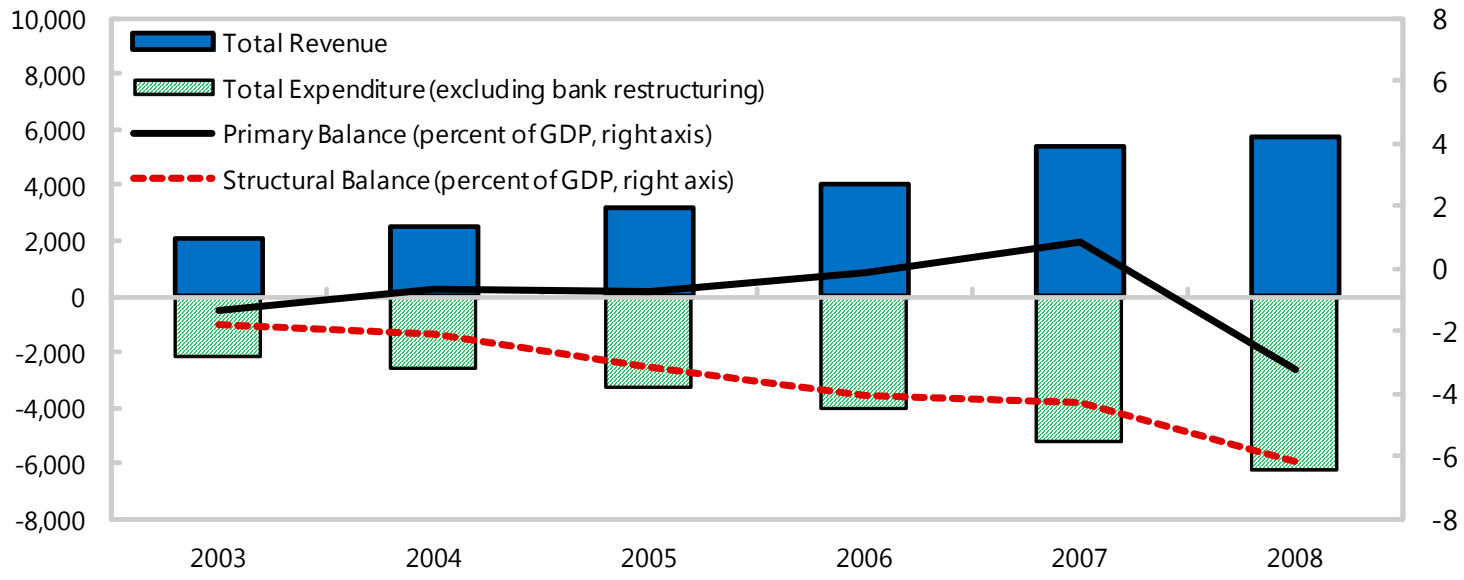

Sources: National authorities; and Fund staff estimates

$1 /$ Excludes bank restructuring costs. 
Figure 2. External Sector Indicators, 2003-08

Current Account

(Percent of GDP)

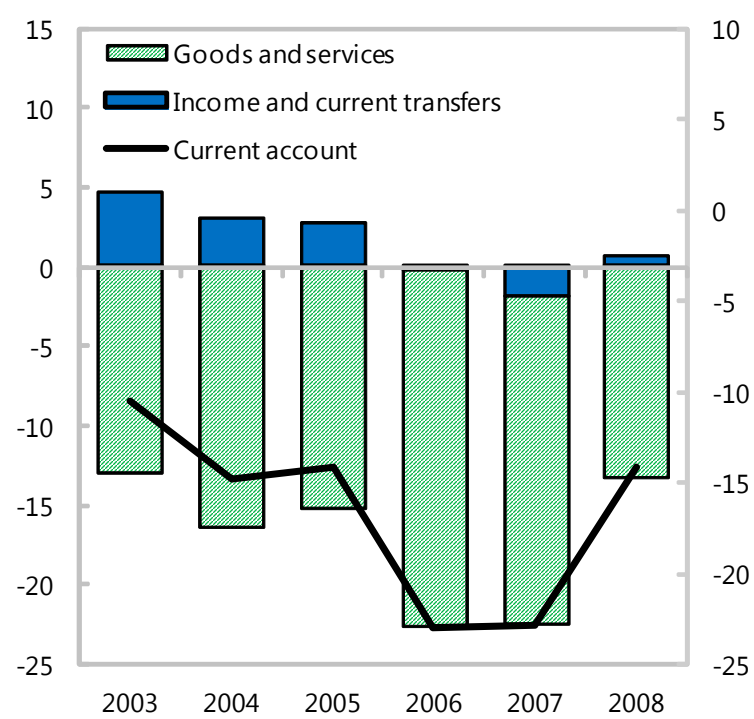

Real Effective Exchange Rates

$(2003=100)$

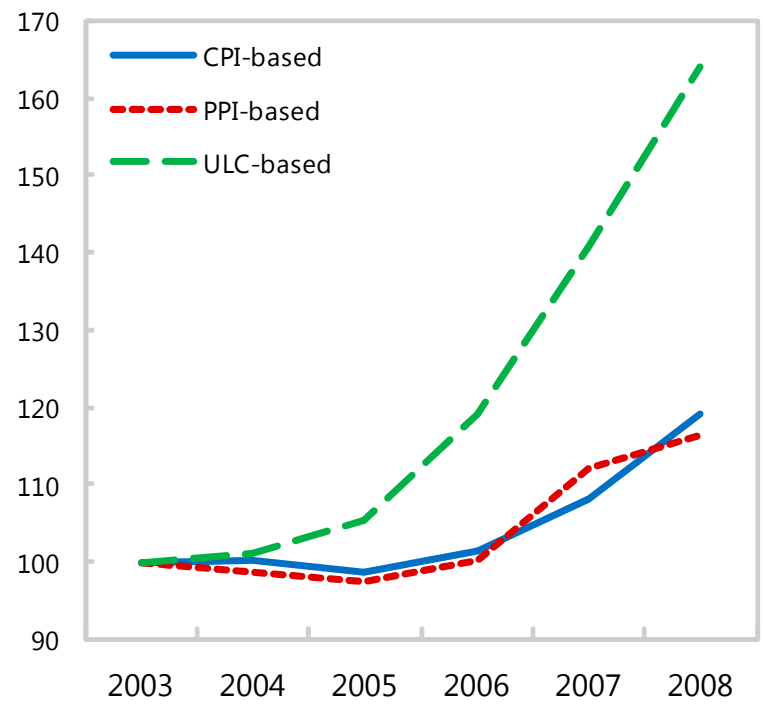

External Debt

(Million euros)

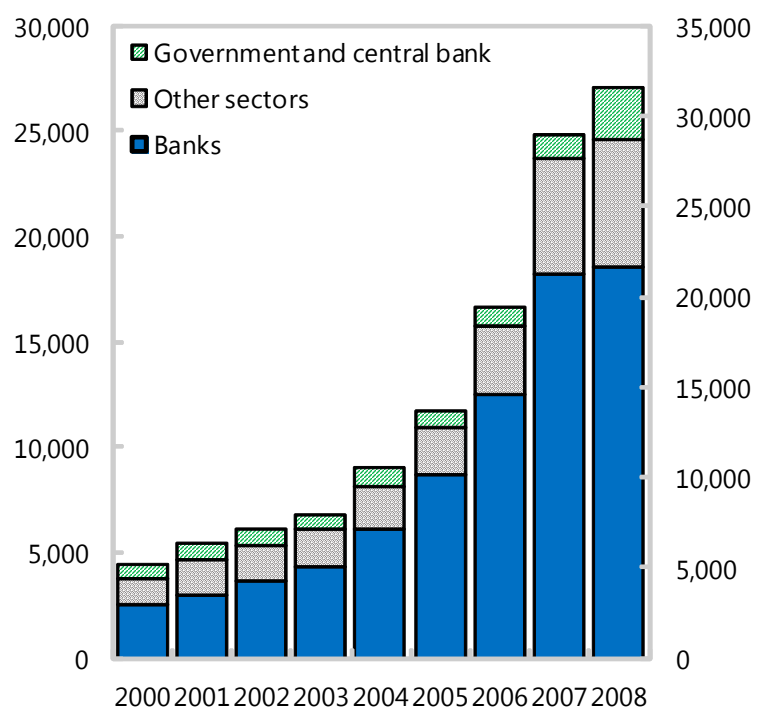

Foreign Reserves

(Percent)

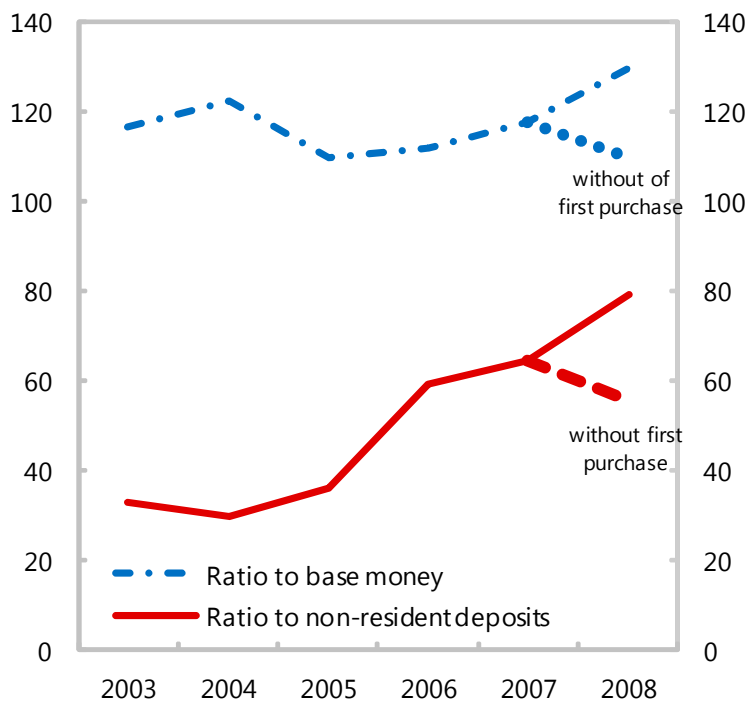

Sources: National authorities; and Fund staff estimates 
Figure 3. Banking Sector Vulnerabilities

(In billion lats unless indicated)

Bank Loans

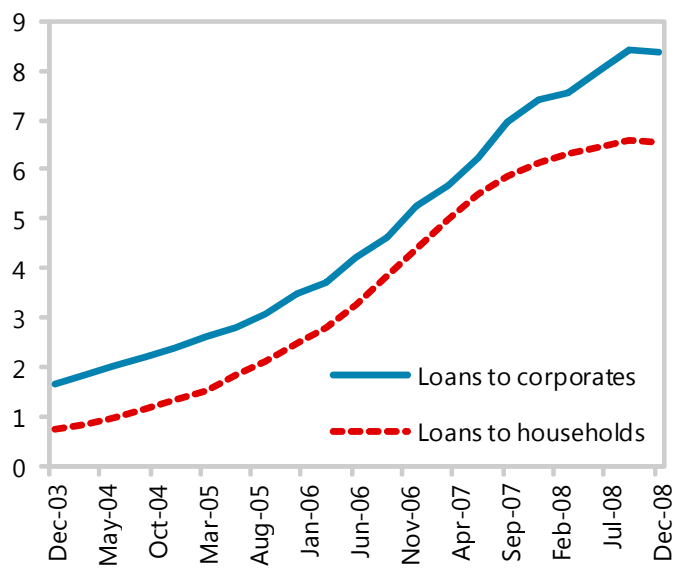

Loan-to-Deposit Ratio

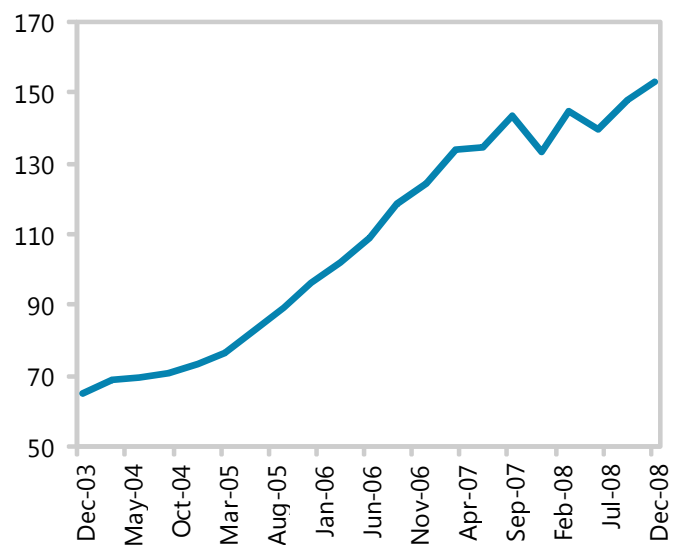

External Debt

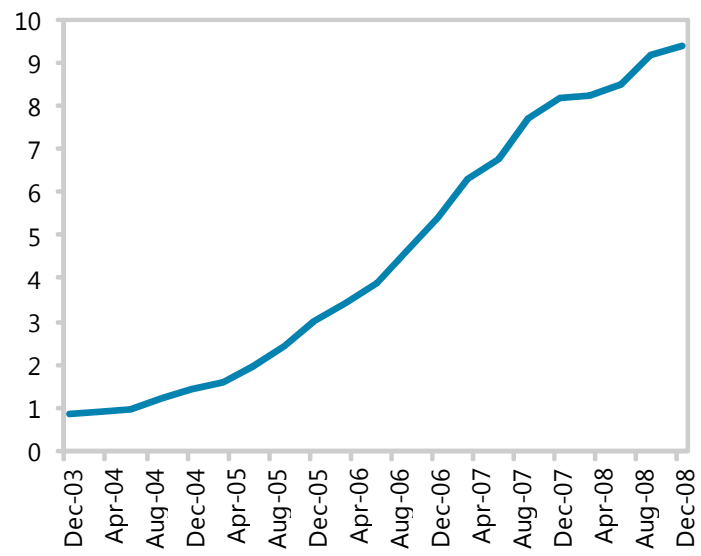

Mortgage Debt

(in percent of GDP)

\begin{tabular}{lc}
\hline Estonia & 32.7 \\
Latvia & 31.0 \\
Lithuania & 19.2 \\
Croatia & 15.3 \\
Hungary & 11.4 \\
Poland & 8.3 \\
Ukraine & 7.1 \\
Bulgaria & 7.0 \\
Kazakhstan & 5.3 \\
Russia & 2.0 \\
\hline Note: Data as of December 2007, except for \\
Lithuania (Oct. 2008) and Latvia (Dec. 2008) \\
Source: Various sources compiled by World Bank
\end{tabular}

Source: FCMC 
Figure 4. Program Projections

Real GDP growth rate

(In percent)

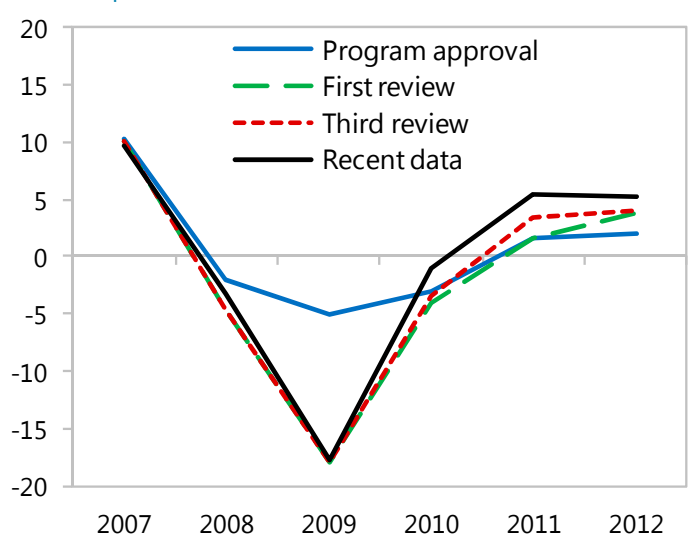

Trade Balance on Goods and Services (In percent of GDP)

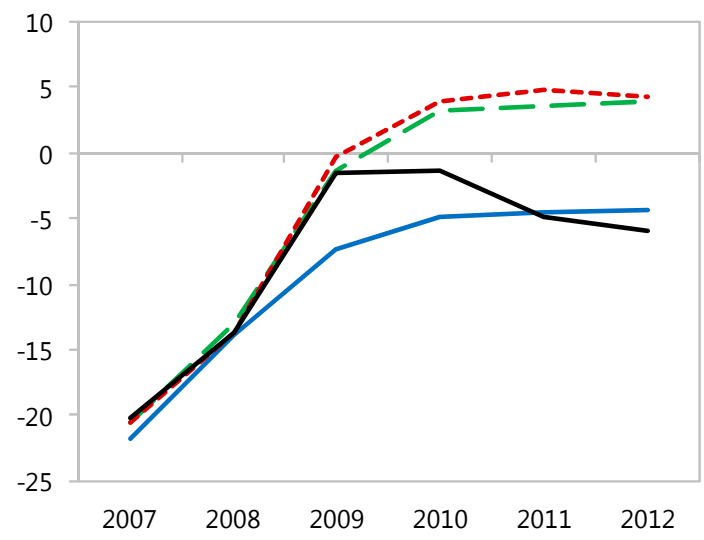

International Reserves

(In billion euros, gross)

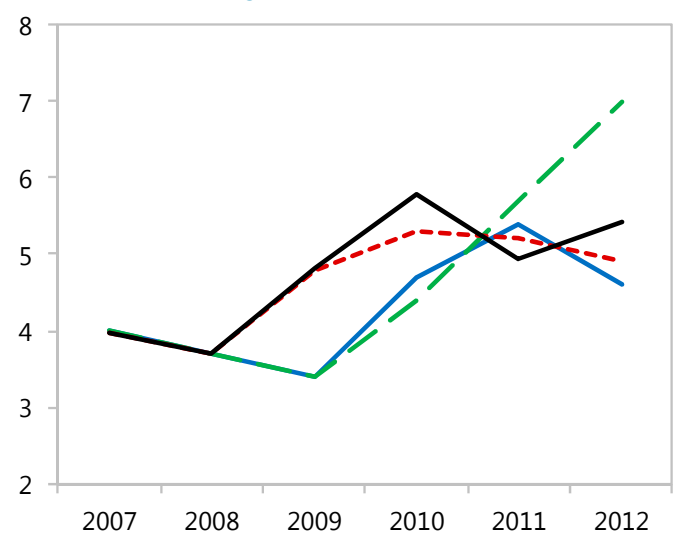

Source: IMF Staff Reports
Inflation

(In percent)

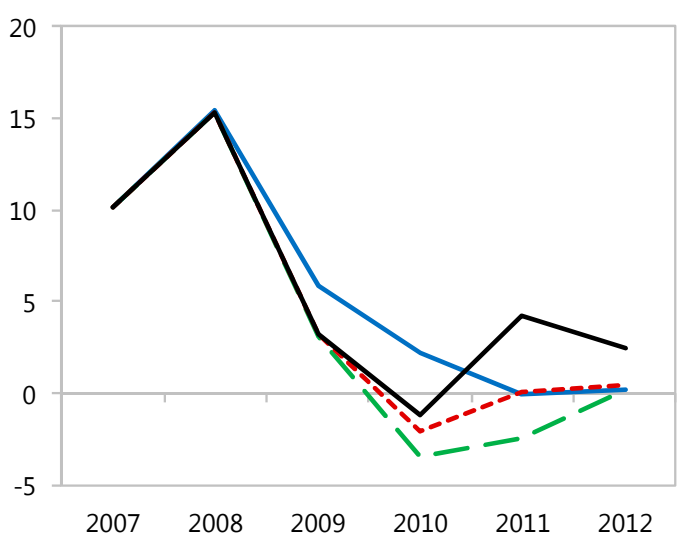

Fiscal balance

(In percent of GDP, excluding restructuring cost)

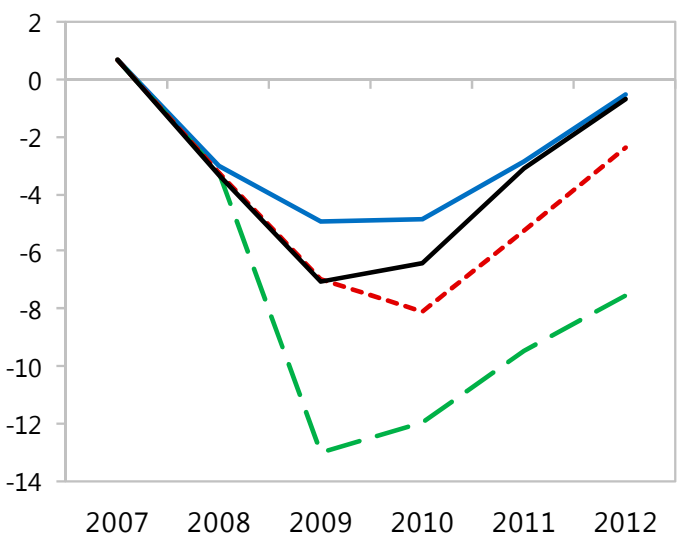

External Debt

(In percent of GDP, gross)

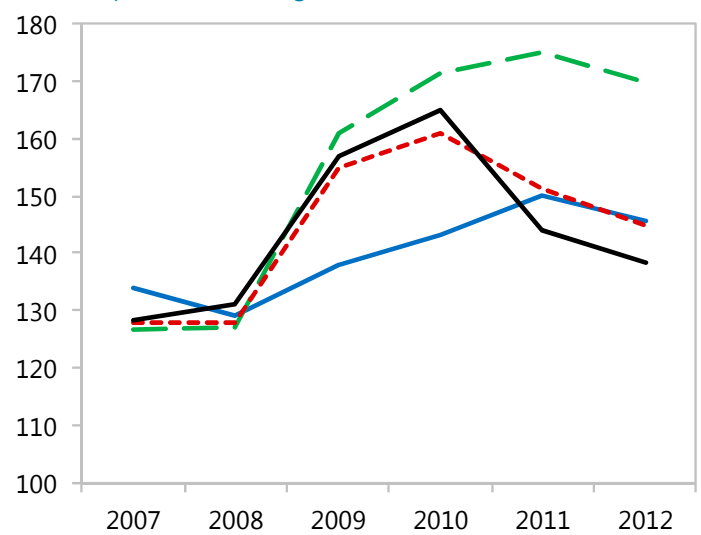


Figure 5. Selected Financial Soundness Indicators

(In percent)

Bank Credit Quality

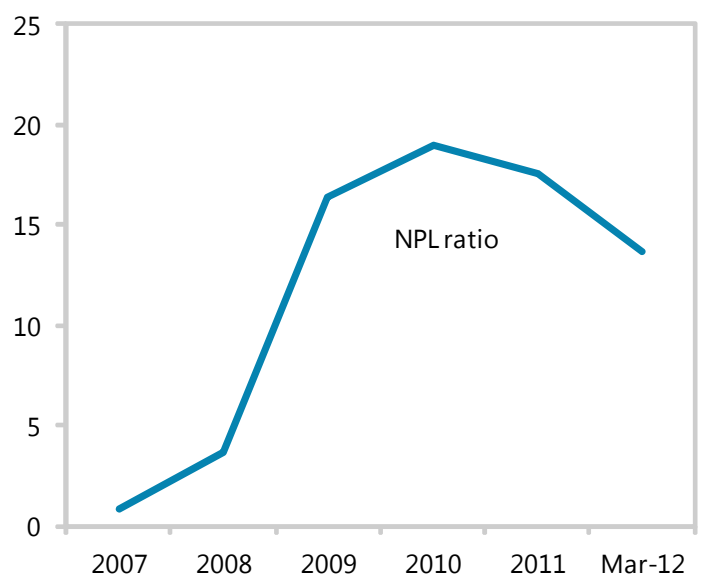

Bank Capitalization

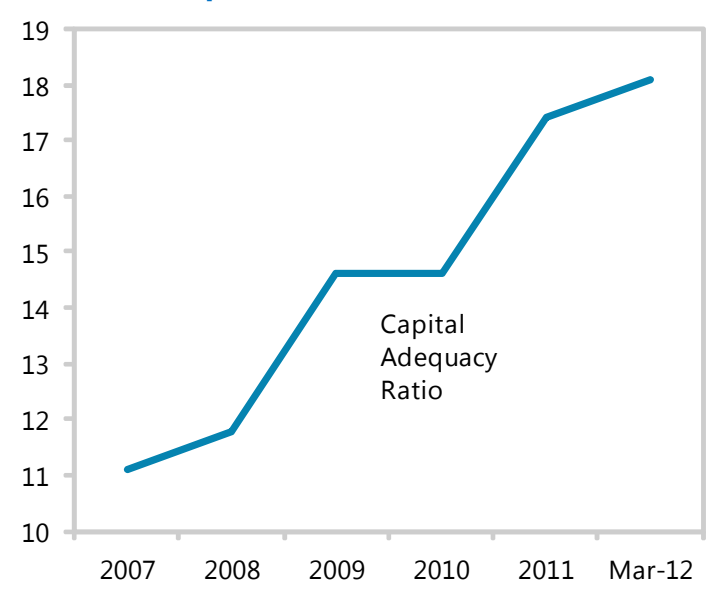

Bank Profitability

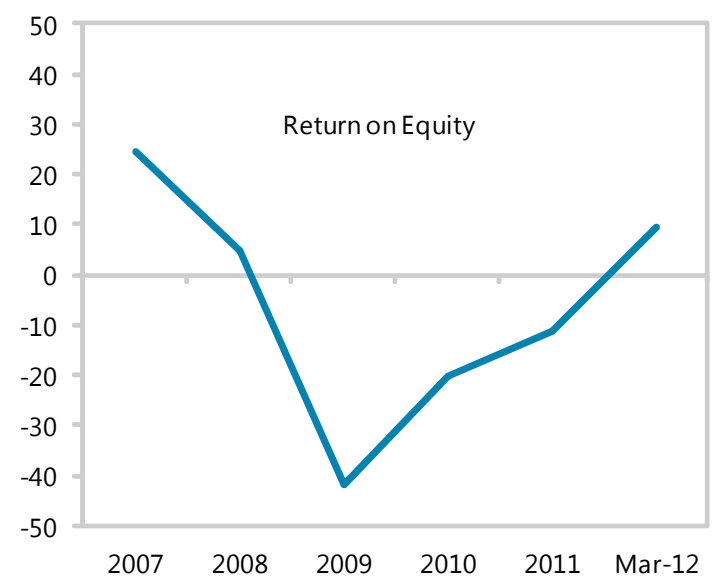

Source: FCMC

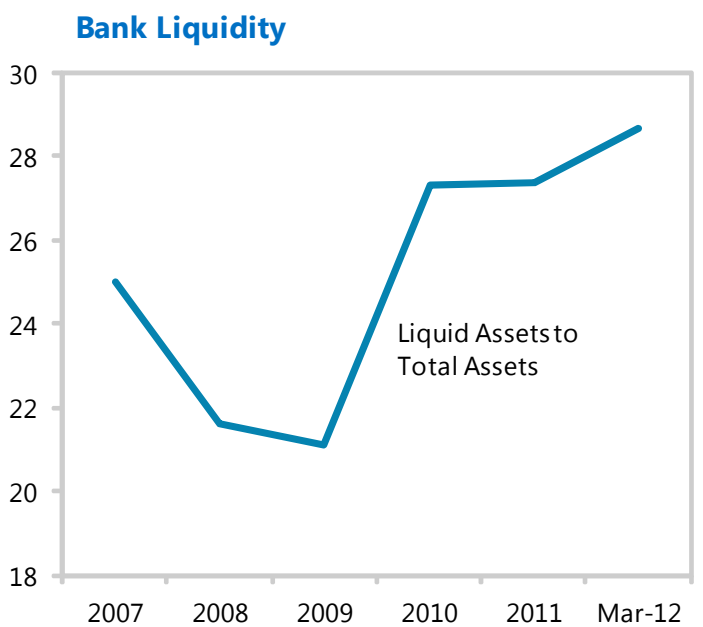

CInternational Monetary Fund. Not for Redistribution 
Figure 6. The Post-Crisis Banking Sector Deleveraging

(In billion lats unless otherwise indicated)

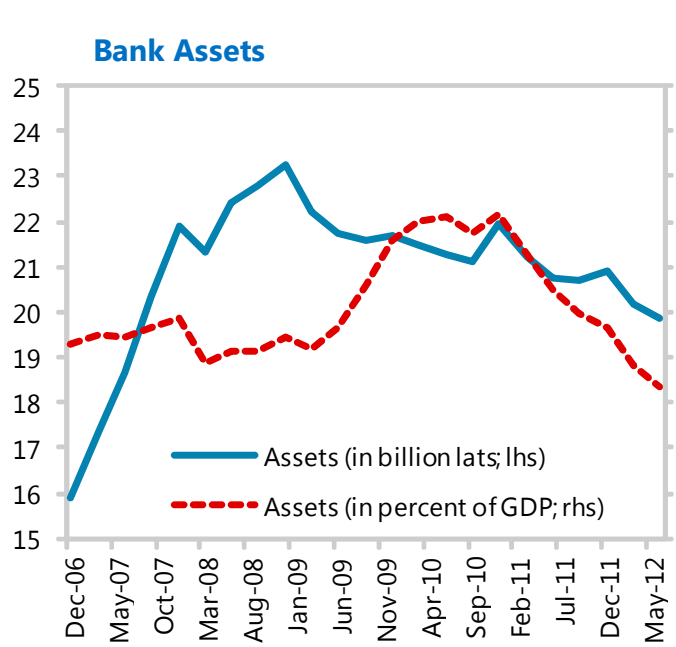

Bank Loans

(In percent of GDP)
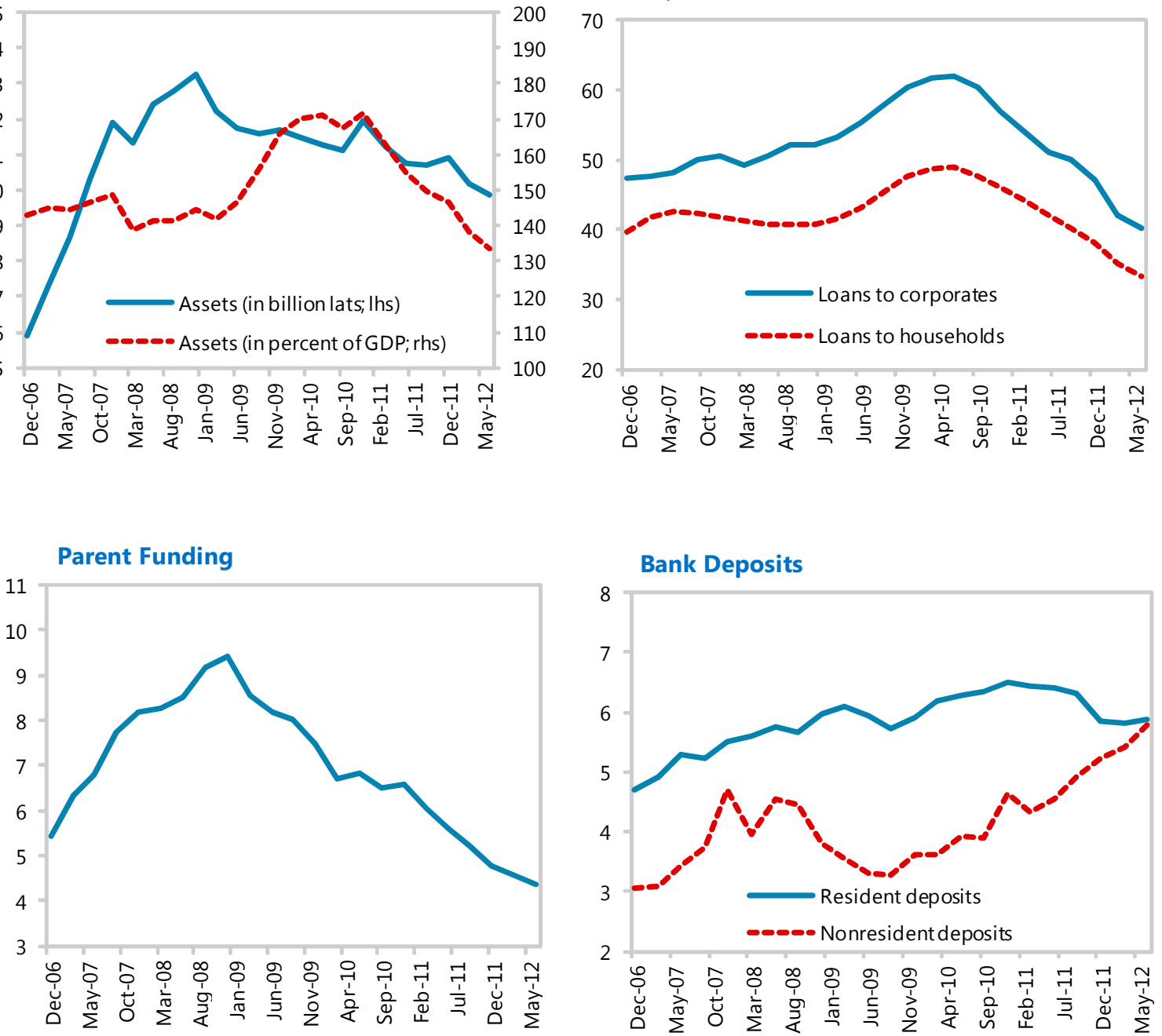

Source: FCMC 


\section{Table 1. Prior Actions, Structural Performance Criteria, and Structural Benchmarks under the 2008 SBA}

\begin{tabular}{|c|c|c|}
\hline Prior Actions & Time of Proposal & Status \\
\hline \multicolumn{3}{|l|}{ Fiscal Policy } \\
\hline - Parliament to adopt a suplementary budget for 2009 with a general government deficit below 5 percent of GDP. & Initial SBA & Met \\
\hline - The government will sign a protocol that stipulates a 15 percent reduction in local government employees' compensation. & Initial SBA & Met \\
\hline \multicolumn{3}{|l|}{ Financial Sector } \\
\hline - The management of Parex Bank to develop a resolution plan considering all options for the bank, and submit it to the FCMC. & Initial SBA & Met \\
\hline \multicolumn{3}{|l|}{ Structural Performance Criteria } \\
\hline \multicolumn{3}{|l|}{ Fiscal Policy } \\
\hline - Submit a supplementary budget law for 2009 to Parliament that will define spending among spending agencies and ministries. & Initial SBA & Met with delay \\
\hline \multicolumn{3}{|l|}{ Structural Benchmarks } \\
\hline \multicolumn{3}{|l|}{ Fiscal Policy } \\
\hline - Adopt a decision of the cabinet of ministers to reform controls on budget execution. & Initial SBA & Met \\
\hline $\begin{array}{l}\text { - Adopt an amendment on fiscal responsibility to the Budget and Financial Management Law to reduce public debt, set } \\
\text { expenditure ceilings, avoid procyclicality in fiscal policy and ultimately allow automatic stabilizers to operate fully. }\end{array}$ & Initial SBA & Not met. \\
\hline $\begin{array}{l}\text { Wages: prepare a comprehensive report on proposed revisions to the public sector wage grid and the relative wage } \\
\text { adjustment across public institutions since end-December } 2008 .\end{array}$ & 1st review & Met, partially \\
\hline - Design a strategy to strengthen the social safety net. & 1st review & Met \\
\hline - Conduct thorough review of welfare benefits. & 2nd review & Met, partially \\
\hline - Pension reform. & 2nd review & Met \\
\hline - Prepare a draft fiscal responsibility law. & 2nd review & Met \\
\hline - Complete strategy paper for defence sector. & 2nd review & Met \\
\hline - Submission to Parliament of a draft Fiscal Responsibility Law in consultation with the IMF and the EC. & 3rd review & Met with delay \\
\hline $\begin{array}{l}\text { Submit a report to Parliament on options ensuring that the Fiscal Responsiblity Law has a greater legal standing than other } \\
\text { laws. }\end{array}$ & 3rd review & Met, partially \\
\hline - Produce a list of state-owned enterprises. & 3rd review & Met \\
\hline - Produce strategy on state-owned enterprises. & 3rd review & Not met \\
\hline - Prepare a menu of options to achieve the 2012 deficit target. & 4th review & Met, partially \\
\hline $\begin{array}{l}\text { Revise the tax compliance strategy, taking into account recommendations of an upcoming technical assistance mission from } \\
\text { the IMF. }\end{array}$ & 4th review & Met with delay \\
\hline - Submission of a 2012 budget to Parliament consistent with the goal of convincingly meeting the Maastricht deficit criterion. & 4th review & Met with delay \\
\hline - Complete a strategy to improve management of state-owned enterprises. & 4th review & Met \\
\hline \multicolumn{3}{|l|}{ Financial Sector } \\
\hline $\begin{array}{l}\text { Adopt operational guidelines for the provision of emergency liquidity assistance (ELA) to clarify procedures for inter-agency } \\
\text { coordination, cross-border arranqements and the treatment of collateral. }\end{array}$ & Initial SBA & Met \\
\hline $\begin{array}{l}\text { Review the new regulation on emergency liquidity support, and if necessary adopt revised regulations, with the aim of ensuring } \\
\text { that they are (i) consistent with international practice, and (ii) provide for adequate safeguards. }\end{array}$ & Initial SBA & Met \\
\hline $\begin{array}{l}\text { Initiate a focused examination of the banking system by international audit firms, to ensure that banks are solvent and have } \\
\text { sufficient liquidity. }\end{array}$ & Initial SBA & Met \\
\hline $\begin{array}{l}\text { Amend the banking laws to allow the FCMC, BoL and the Ministry of Finance to take timely and effective actions to restore } \\
\text { financial stability in systemic crises and ehnace the special bank insolvency regime }\end{array}$ & Initial SBA & Met \\
\hline Prepare a strategy for bank recapitalization and resolution. & 1st review & Met \\
\hline $\begin{array}{l}\text { Financial sector monitoring: (i) seek international assistance to improve stress-testing capacity; strengthen co-operation } \\
\text { between the BoL and FCMC in this area; and (ii) increase resources available to FCMC to perform off-site monitoring }\end{array}$ & 1st review & Met \\
\hline - Submission to Parliament of amendments to the Insolvency Law and other credit enforcement laws. & 1st review & Met with delay \\
\hline - Revise liquidity regulations. & 2nd review & Met \\
\hline - Submit Parex restructuring plan to European Commission. & 2nd review & Met \\
\hline - Establish Deposit Guarantee Fund as separate unit with separate financial statements. & 2nd review & Met \\
\hline - Complete action plan for Mortgage and Land Bank. & 2nd review & Met with delay \\
\hline - Revise credit risk management regulation. & 2nd review & Met \\
\hline $\begin{array}{l}\text { - Prepare a report on whether any legislative changes are necessary to allow credit institutions, their subsidiaries, and separated } \\
\text { entities to deduct losses from debt write-downs against corporate income tax. }\end{array}$ & 3rd review & Met with delay \\
\hline - Engage a reputable and qualified independent advisor to assist with formulation of a transformation plan for MLB. & 3rd review & Met with delay \\
\hline $\begin{array}{l}\text { Parliamentary approval of revisions to tax legislation to allow credit institutions to deduct losses from debt write-downs } \\
\text { against corporate income tax. }\end{array}$ & 3rd review & Met with delay \\
\hline - Introduce a temporary one-year waiver for personal income tax liabilities resulting from debt write-downs. & 3rd review & Met with delay \\
\hline $\begin{array}{l}\text { Hire a qualified, experienced, and independent sales consultant mobilizing a team of internationally reputable experts to } \\
\text { prepare and run the MLB sales strategy. }\end{array}$ & 4th review & Met with delay \\
\hline $\begin{array}{l}\text { Submit a MLB sales strategy to the EC and appoint a qualified and independent head of restructuring with international } \\
\text { experience to oversee the restructuring and sales process. }\end{array}$ & 4th review & Met with delay \\
\hline - Submit amendments to the initial proposal to amend the Civil Procedure Law to Parliament. & 4th review & Met with delay \\
\hline - Sell the commercial part of MLB. & 4th review & Delayed \\
\hline \multicolumn{3}{|l|}{ Other } \\
\hline - Develop a comprehensive debt restructuring strategy. & Initial SBA & Met with delay \\
\hline - Amend the insolvency law in order to facilitate orderly and efficient debt restructurings. & Initial SBA & Met \\
\hline - Wages: reform the Committee to Promote Wage Restraint by involving the social partners and outside labor market experts. & 1st review & Met \\
\hline - Review debt restructuring scheme. & 2nd review & Not met \\
\hline - Prepare menu of potential structural reforms. & 2nd review & Met \\
\hline - Prepare an active labour market policy (ALMP) strategy that will replace the WWS program. & 4th review & Met \\
\hline
\end{tabular}

\section{CInternational Monetary Fund. Not for Redistribution}




\section{Table 2. Quantitative Performance Criteria, Indicative Targets}

and Continuous Performance Criteria under the 2008 SBA

\begin{tabular}{|c|c|c|c|c|c|c|c|c|c|c|c|c|c|c|c|c|c|c|c|c|}
\hline \multirow{4}{*}{$\begin{array}{l} \\
\\
\text { I. Quantitative performance criteria } \\
\text { Floor on: }\end{array}$} & \multicolumn{6}{|c|}{ Program (Dec 08) } & \multicolumn{4}{|c|}{ 1st review (Aug 09) } & \multirow{2}{*}{\multicolumn{2}{|c|}{$\frac{\text { 2nd review (Feb 10) }}{\text { Mar-10 }}$}} & \multicolumn{6}{|c|}{ 3rd review (Jul 10) } & \multirow{2}{*}{\multicolumn{2}{|c|}{$\frac{4 \text { th review (Jun } 11}{\text { Aug-11 }}$}} \\
\hline & \multirow{2}{*}{\multicolumn{2}{|c|}{$\frac{\text { Dec-08 }}{\text { Target Actual }}$}} & \multirow{2}{*}{\multicolumn{2}{|c|}{$\frac{\text { Mar-09 }}{\text { Target Actual }}$}} & \multirow{2}{*}{\multicolumn{2}{|c|}{$\frac{\text { Jun-09 }}{\text { Target Actual }}$}} & \multirow{2}{*}{\multicolumn{2}{|c|}{$\frac{\text { Sep-09 }}{\text { Target Actual }}$}} & \multirow{2}{*}{\multicolumn{2}{|c|}{$\frac{\text { Dec-09 }}{\text { Target Actual }}$}} & & & \multirow{2}{*}{\multicolumn{2}{|c|}{$\frac{\text { Jun-10 }}{\text { Target Actual }}$}} & \multirow{2}{*}{\multicolumn{2}{|c|}{$\frac{\text { Sep-10 }}{\text { Target Actual }}$}} & \multirow{2}{*}{\multicolumn{2}{|c|}{$\frac{\text { Dec-10 }}{\text { Target Actual }}$}} & & \\
\hline & & & & & & & & & & & Target & Actual & & & & & & & Target $\mathrm{A}$ & \multirow[t]{2}{*}{ Actual } \\
\hline & & & & & & & & & & & & & & & & & & & & \\
\hline $\begin{array}{l}\text { Net international reserves of } \\
\text { the Bank of Latvia (mln euros) }\end{array}$ & 2,103 & 2,700 & 737 & 1,733 & -507 & 1,163 & -81 & 1,402 & -586 & 1,347 & 29 & 1,451 & -361 & 1,415 & 839 & 1,586 & 286 & 1,200 & 463 & 1,110 \\
\hline $\begin{array}{l}\text { Adjusted cash (non-EU) fiscal } \\
\text { balance (mln lats) }\end{array}$ & -894 & $-957^{*}$ & -305 & $-328^{*}$ & -649 & $-794^{*}$ & $\ldots$ & $\ldots$ & $\ldots$ & $\ldots$ & $\ldots$ & $\ldots$ & $\ldots$ & $\ldots$ & $\ldots$ & $\ldots$ & $\ldots$ & $\ldots$ & $\ldots$ & $\cdots$ \\
\hline $\begin{array}{l}\text { Adjusted primary cash fiscal } \\
\text { balance (mln lats) } \\
\text { Ceiling on: }\end{array}$ & $\ldots$ & $\ldots$ & $\ldots$ & $\ldots$ & $\ldots$ & $\ldots$ & -828 & -467 & $-1,289$ & -746 & -116 & -94 & -338 & -100 & -401 & -135 & $-782^{\top}$ & -319 & -33 & 125 \\
\hline Net domestic assets of the & 951 & 423 & 1,434 & 419 & 2,501 & 768 & 1,719 & 619 & 2,103 & 699 & 1,679 & 445 & 1,199 & 708 & 1,911 & 696 & 1,596 & 968 & 1,482 & 1156 \\
\hline $\begin{array}{l}\text { Bank of Latvia (mln lats) } \\
\text { Public guarantees (mln lats) }\end{array}$ & $\ldots$ & $\ldots$ & $\ldots$ & $\ldots$ & $\ldots$ & $\ldots$ & 754 & 312 & 754 & 328 & 836 & 379 & 836 & 389 & 754 & 416 & 754 & 426 & 754 & 453 \\
\hline $\begin{array}{l}\text { II. Continuous performance criteria } \\
\text { Ceiling on: }\end{array}$ & & & & & & & & & & & & & & & & & & & & \\
\hline $\begin{array}{l}\text { General government } \\
\text { domestic arrears (mln lats) }\end{array}$ & 0 & 0 & 0 & $6^{*}$ & 0 & $11^{*}$ & 40 & 12 & 40 & 12 & 40 & 12 & 40 & 15 & 40 & 12 & 40 & 5 & 40 & 9 \\
\hline External debt arrears (mln & 0 & 0 & 0 & 0 & 0 & 0 & 0 & $8^{*}$ & 0 & $8^{*}$ & 0 & 0 & 0 & 0 & 0 & 0 & 0 & 0 & 0 & 0 \\
\hline $\begin{array}{l}\text { III. Indicative target } \\
\text { Ceiling on: }\end{array}$ & & & & & & & & & & & & & & & & & & & & \\
\hline $\begin{array}{l}\text { General government wage } \\
\text { bill }\end{array}$ & 1,248 & $1267^{*}$ & 214 & $263^{*}$ & 490 & $598^{*}$ & 840 & 805 & 1,067 & 1,028 & 194 & 188 & 457 & 423 & 654 & 604 & 948 & 846 & 635 & 570 \\
\hline
\end{tabular}


Table 3. Selected Economic Indicators, 2008-12

\begin{tabular}{|c|c|c|c|c|c|}
\hline & 2008 & 2009 & 2010 & 2011 & 2012 \\
\hline & & & & \multicolumn{2}{|c|}{ Proj. } \\
\hline National accounts & \multicolumn{5}{|c|}{ (percentage change, unless otherwise indicated) } \\
\hline Real GDP & -3.3 & -17.7 & -0.9 & 5.5 & 5.2 \\
\hline Private consumption & -5.8 & -22.6 & 2.4 & 4.8 & 6.0 \\
\hline Gross fixed capital formation & -13.8 & -37.4 & -18.1 & 27.9 & 9.5 \\
\hline Exports of goods and services & 2.0 & -14.1 & 11.6 & 12.7 & 6.1 \\
\hline Imports of goods and services & -10.8 & -33.3 & 11.4 & 22.7 & 7.0 \\
\hline Nominal GDP (billions of lats) & 16.1 & 13.1 & 12.8 & 14.3 & 15.3 \\
\hline Nominal GDP (billions of euros) & 22.7 & 18.6 & 18.2 & 20.5 & 21.8 \\
\hline GDP per capita (thousands of euros) & 10.0 & 8.2 & 8.1 & 9.9 & 10.7 \\
\hline \multicolumn{6}{|l|}{ Savings and Investment } \\
\hline Gross national saving (percent of GDP) & 18.0 & 29.2 & 22.8 & 24.7 & 25.5 \\
\hline Gross capital formation (percent of GDP) & 31.2 & 20.5 & 19.8 & 26.8 & 27.7 \\
\hline Private (percent of GDP) & 26.6 & 17.2 & 16.8 & 22.7 & 23.6 \\
\hline \multicolumn{6}{|l|}{ HICP inflation } \\
\hline Period average & 15.3 & 3.3 & -1.2 & 4.2 & 2.4 \\
\hline End-period & 10.4 & -1.4 & 2.4 & 3.9 & 2.2 \\
\hline \multicolumn{6}{|l|}{ Labor market } \\
\hline Unemployment rate (LFS definition; period average, percent) 1 & 7.5 & 16.9 & 18.7 & 16.2 & 15.0 \\
\hline \multirow[t]{2}{*}{ Real gross wages } & 4.4 & -6.8 & -2.3 & 0.0 & 1.3 \\
\hline & \multicolumn{5}{|c|}{ (percent of GDP, unless otherwise indicated) } \\
\hline Consolidated general government 2/ & & & & & \\
\hline Total revenue & 35.6 & 36.2 & 36.0 & 35.6 & 38.0 \\
\hline Total expenditure & 39.0 & 43.3 & 42.4 & 38.7 & 38.7 \\
\hline Basic fiscal balance & -3.4 & -7.1 & -6.4 & -3.1 & -0.7 \\
\hline ESA balance & -4.2 & -9.7 & -8.2 & -3.4 & -1.8 \\
\hline General government gross debt & 17.2 & 32.9 & 39.7 & 37.5 & 37.6 \\
\hline \multicolumn{6}{|l|}{ Money and credit } \\
\hline Credit to private sector (annual percentage change) & 11.0 & -6.9 & -8.4 & -7.4 & -9.0 \\
\hline Broad money (annual percentage change) & -3.9 & -1.9 & 9.8 & 1.5 & 2.5 \\
\hline Residents' FX deposits (percent of total deposits) & 48.6 & 55.6 & 50.3 & 51.7 & 54.1 \\
\hline Treasury Bill rate (365 days, eop, percent) & 11.0 & 10.2 & 1.8 & 1.7 & $\ldots$ \\
\hline Money market rate (one month, eop, percent) & 13.3 & 2.7 & 0.6 & 1.1 & $\ldots$ \\
\hline \multicolumn{6}{|l|}{ Balance of payments } \\
\hline Gross official reserves (billions of euros) & 3.7 & 4.8 & 5.8 & 4.9 & 5.4 \\
\hline (In months of prospective imports) & 5.4 & 5.9 & 5.5 & 4.2 & 4.2 \\
\hline (percent of broad money and non-resident deposits) & 75.2 & 96.0 & 119.0 & 112.8 & 147.4 \\
\hline Current account balance & -13.2 & 8.7 & 3.0 & -2.1 & -2.2 \\
\hline Trade balance & -17.9 & -7.1 & -7.0 & -10.7 & -11.9 \\
\hline Gross external debt & 130.9 & 156.8 & 165.1 & 143.9 & 138.3 \\
\hline Net external debt $3 /$ & 57.5 & 58.8 & 54.2 & 46.0 & 39.5 \\
\hline \multicolumn{6}{|l|}{ Exchange rates } \\
\hline Lats per euro (period average) $/ 4$ & 0.71 & 0.70 & 0.70 & 0.70 & $\ldots$ \\
\hline Lats per U.S. dollar (period average) & 0.48 & 0.51 & 0.53 & 0.50 & $\ldots$ \\
\hline REER (period average; CPI based, $2000=100$ ) & 104.5 & 110.2 & 103.6 & 103.8 & $\ldots$ \\
\hline
\end{tabular}

Sources: Latvian authorities; Eurostat; and IMF staff estimates.

1/ LFS statistics were revised in 2011 in compliance with population census; data before 2011 have not been revised yet. 2/ National definition. Includes economy-wide EU grants in revenue and expenditure.

$3 /$ Gross external debt minus gross external debt assets.

4 / Lat is pegged to the euro at $1 \mathrm{EUR}=0.702804 \mathrm{LVL}$ rate, with \pm 1 percent band. 
Annex I. The Latvian Authorities' Views on the Ex-Post Evaluation ${ }^{1}$

\section{General remarks}

The authorities broadly agree with the conclusions of the Ex-Post Evaluation (EPE) paper. The design of conditionality properly addressed the challenges the Latvian authorities faced in implementing the necessary reforms and adjustment, and the level of access was appropriately large to instill the necessary confidence in markets. With the latest issuance in December 2012 of seven-year USD bonds at a yield of 2.89 percent Latvia is firmly back in the markets.

The objectives of the EPEs are narrowly defined and while the authorities do not doubt that sufficient safeguards are in place, the EPEs are internal evaluations, essentially, staff assessing staff. It is difficult to disagree with the analysis of the EPE, but the conclusions hardly strike the authorities as particularly exhaustive or insightful. In the following few paragraphs the Latvian authorities offer some comments on issues which could have been reviewed in more detail.

\section{The program}

The program was marked by some delays, though staff's conservative fiscal projections, and accordingly excessively large disbursements, explained part of it. As noted in the EPE paper, the election cycle probably mattered. In addition, fiscal over-performance in later reviews provided an incentive not to hurry with reviews. Contracting new debt in circumstances when large share of previous disbursements was not used and part of it was locked for potential use by the financial sector would be a difficult move to sell domestically. That said, the authorities agree with the report that the high level of access was material in building confidence. Also, considering that some reversals of measures are inevitable under circumstances of large budget cuts, staff's conservative growth projections after the first review were probably appropriate.

The EPE paper correctly describes the events in the beginning of the program but more attention could have been paid to the decisive discussions around the first review. The perceived rift with the European Commission, the following EU disbursement, and the subsequent rather eccentric first review report could provide much material for analysis. The first review went out featuring two scenarios - the authorities' "rapid adjustment scenario" and staff's "program scenario". In retrospect, the extremely large errors of the projections indicate that limited understanding of either the authorities' intentions or/and the mechanics of the economy was present.

\footnotetext{
${ }^{1}$ This annex is prepared by the Latvian authorities.
} 
Here are a couple of figures to illustrate the point.

\section{$1^{\text {st }}$ review staff projections}

Manufacturing exports

(millions of euros)

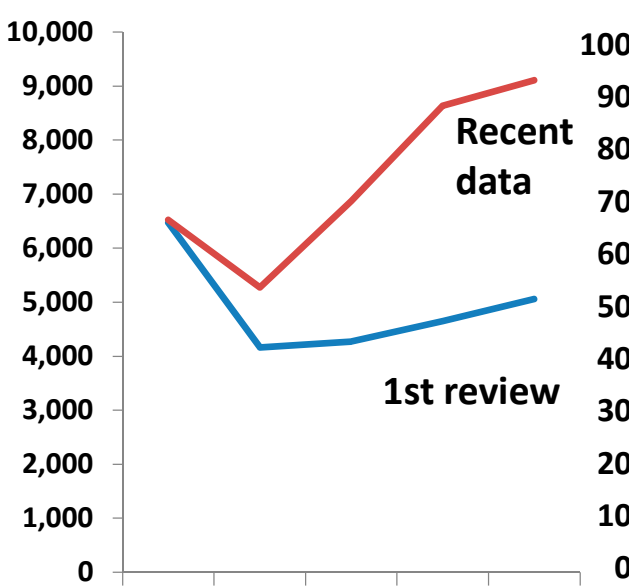

20082009201020112012
Public debt projections

(\% of GDP)

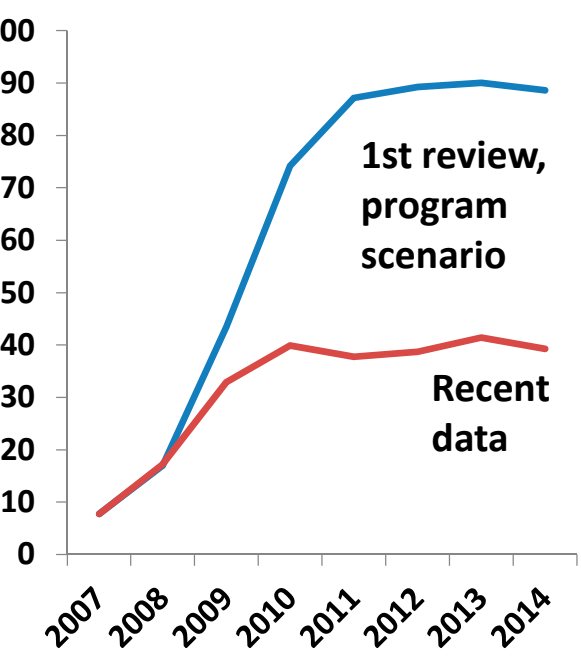

Manufacturing exports were supposed to linger almost indefinitely under the 2007 level and staff's preferred "program scenario" projected the public debt to peak at 90 percent of GDP. Considering that this level of debt level was well-above the "maximum sustainable debt" levels established in the literature by $2009^{2}$, the projection clearly hinted at a considerable risk of a default. The whole discussion around the first review was heated and from the authorities' perspective, some of the assumptions behind staff's pessimistic projections remained enigmatic. On behalf of the Latvian authorities, the Swedish Executive Director wrote in his statement to the IMF Board "While respecting staff estimates, we clearly see that notable buffers have been built into the 2010 budget baseline and consequently the program scenario...". The authorities can only speculate on the possible reasons behind the export projections but it seems that staff had misread how economies under fixed exchange rate adjust. ${ }^{3}$

\footnotetext{
${ }^{2}$ The Board paper on Modernizing the Framework for Fiscal Policy and Public Debt Sustainability Analysis notes that the estimates prior to 2009 in the literature of the level of "beyond which a debt distress event is likely or inevitable" in emerging markets are in the range of 35 to 77 percent.

${ }^{3}$ A similar belief that adjustment under fixed exchange rate was almost impossible was shared by many. Reportedly, in June 2009 Kenneth Rogoff said that with a fixed exchange rate Latvia "will never survive" (link: http://swedishwire.com/stock-market-update/412-harvard-professor-latvia-must-devaluate)
} 
The distancing from the authorities' strategy during 2009 and 2010 was not very helpful in the authorities' efforts to restore market confidence. The turning point of the program was the European Commission's decision in July 2009 to disburse their part without a formal agreement with the Fund staff. Though after the IMF Board had decided to go ahead with the first review, the authorities would have expected more public communication efforts to clear the doubts that markets had about the Fund's ownership of the program.

Unfortunately, the quality of communication improved only gradually and at a rather late stage of the program.

The subsequent reviews, while still contentious, followed comparatively smoothly. The perceived uncertainty during 2009 and the first half of 2010 acted as a drag on recovery, suppressing domestic demand and investment. Growth picked up in 2011 and the recent projections for 2012 indicate that Latvia is experiencing a debt crisis gravity-defying growth, likely to exceed 5 percent.

\section{Why success?}

Strong ownership was the key factor behind the success. It really was the authorities' program from the beginning to the end. It was obvious during the inception phase and in June 2009 when there was some disagreement between the authorities and the Fund. The other side of the coin was that this time the Fund was indeed sufficiently flexible to accommodate the authorities' strategy, although, it is difficult to judge to what extent the fact that regional partners with their financing were involved in the program mattered in this context.

\section{Adding to that, the speed of the adjustment and involvement of regional partners were} important factors contributing to the outcome. While it is in no way a universal recipe for dealing with crises, the frontloaded nature of adjustment helped with credibility and was instrumental in the program's success. Similar adjustment strategies but without Fund programs were successful in Estonia and Lithuania. The European Commission brought additional flexibility with regards to the program's strategy to the table and their knowledge of local and regional specifics was also very important. The Nordic partners, on their part, secured that foreign-owned banks deleverage in an orderly way.

While the program was a success, scars, not so much of the program, as of the preceding bubble remains. High unemployment and emigration are two main issues requiring decisive actions. However, doomsayers will probably find it increasingly difficult to justify the dramatic tone. ${ }^{4}$ In 2013, Latvia's GDP per capita is expected to exceed the peak level of

\footnotetext{
${ }^{4}$ In 2008, Paul Krugman conjured a headline "Latvia is the new Argentina (slightly wonkish)". By the end of 2009 , views along those lines had been endorsed by many, e.g. Simon Johnson, Nouriel Roubini.
} 
2007. ${ }^{56}$ In the same year, this back-to-2007 threshold will be crossed by many other economies (among them, some reserve currency issuers) that have experienced much shallower recessions. For Latvia, this figure will be reached in sustainable way - the quality of this 2013 GDP will be quite different from the 2007 GDP, when it was built on a housing bubble and over 20 percent current account deficits.

\footnotetext{
${ }^{5}$ Note that for GDP per capita migration flows matter.

${ }^{6}$ Though PPP GDP is not the best variable to be used in year-to-year comparisons, it should be noted that in PPP terms this threshold was crossed already in 2011.
} 


\section{IMF Executive Board Concludes 2012 Article IV Consultation and Second Post-Program Monitoring Discussions, and Ex-Post Evaluation of Exceptional Access Under the 2008 Stand-By Arrangement with the Republic of Latvia}

On January 23, 2013, the Executive Board of the International Monetary Fund (IMF) concluded the 2012 Article IV consultation ${ }^{1}$ and the Second Post-Program Monitoring Discussions ${ }^{2}$, and the Ex-Post Evaluation of Exceptional Access Under the 2008 Stand-By Arrangement ${ }^{3}$ with the Republic of Latvia.

\section{Background}

Latvia continues to rebound vigorously from the deep downturn in 2008-09, despite recession in the euro area. Real GDP growth of 5.5 percent in 2011 and 5.7 percent in the first three quarters of 2012 was underpinned by both external and domestic demand. Strong job creation has resulted in falling unemployment, but the unemployment rate remains high at about

\footnotetext{
${ }^{1}$ Under Article IV of the IMF's Articles of Agreement, the IMF holds bilateral discussions with members, usually every year. A staff team visits the country, collects economic and financial information, and discusses with officials the country's economic developments and policies. On return to headquarters, the staff prepares a report, which forms the basis for discussion by the Executive Board. At the conclusion of the discussion, the Managing Director, as Chairman of the Board, summarizes the views of Executive Directors, and this summary is transmitted to the country's authorities. An explanation of any qualifiers used in summings up can be found here: http://www.imf.org/external/np/sec/misc/qualifiers.htm.

${ }^{2}$ Post-Program Monitoring provides for more frequent consultations between the Fund and members whose arrangement has expired but that continue to have Fund credit outstanding, with a particular focus on policies that have a bearing on external viability. There is a presumption that members whose credit outstanding exceeds 200 percent of quota would engage in Post-Program Monitoring.

${ }^{3}$ The requirement for ex post evaluations (EPEs) was agreed by the IMF Executive Board in September 2002 for members using exceptional access in capital account crises, and extended to any use of exceptional access in February 2003. The purpose of the EPE is to provide a critical and frank discussion of whether justifications presented at the outset of the arrangement-including the justification for exceptional access - were consistent with Fund policies and to review performance under the Fund-supported program.
} 
15 percent, and half of the unemployed have been out of work for more than a year. Consumer price inflation has declined sharply from its peak, averaging [2.4] percent in 2012. Robust export growth is expected to keep the current account deficit at about 2 percent despite recovering import demand. Latvia has successfully returned to international markets.

As a result of fiscal consolidation measures over the last 4 years, Latvia reduced its general government deficit from nearly 10 percent of GDP in 2009 (ESA 95 definition) to 3.4 percent of GDP in 2011. Despite a 1 percentage point mid-year reduction in the statutory VAT rate and a supplementary budget containing additional expenditures, revenue over performance helped reduce the deficit to below 2 percent of GDP in 2012. The 2013 budget further cements past fiscal gains and should be consistent with both the Maastricht deficit criterion and the Stability and Growth Pact.

The banking system returned to profitability in 2011 and is well capitalized. Credit to residents has contracted substantially since the onset of the crisis, but the rate of contraction has been declining and is likely to level off soon. Non-resident deposits (NRDs) in the banking system-a potential source of vulnerability to international reserves-have been expanding rapidly, but to a large extent this process has been matched by an accumulation of liquid foreign assets.

The government aims at euro adoption in 2014. The country is well-positioned to meet all the Maastricht criteria in 2013. Joining the euro would remove residual currency risk, adding stability to the Latvian economy.

\section{Executive Board Assessment}

Executive Directors agreed with the thrust of the staff appraisal. They welcomed Latvia's early repayment of all outstanding obligations to the Fund following the successful international bond issuance, which reflects renewed confidence in the economy and the authorities' policies. The economy continues to recover strongly, inflation has fallen sharply, and the current account deficit is modest. While the medium-term economic outlook is favorable, risks are tilted to the downside because of the uncertain external environment. Directors emphasized the need for continued strong policies to safeguard financial stability, tackle persistently high structural unemployment, and strengthen potential growth.

Directors commended the authorities' remarkable fiscal adjustment and welcomed that the 2013 budget appropriately consolidates the fiscal gains, holding the budget deficit well below the Maastricht criterion. They called for sustaining measures to build fiscal space and avoid the resurgence of imbalances. Directors urged the authorities to keep the lowering of the Guaranteed Minimum Benefit and the decentralization of its financing under close review to ensure that the system continues to provide adequate support to the most vulnerable and avoids deepening regional disparities. They welcomed the authorities' readiness to reconsider the issue in light of the upcoming World Bank report. While some Directors saw merit in the planned cuts to the personal income tax in order to improve work incentives, others urged caution given concerns 
about equity and fiscal space, and highlighted the need for compensatory measures. Directors agreed that structural fiscal reforms, including timely passage and effective implementation of the Fiscal Discipline Law, will be crucial to strengthening fiscal sustainability.

Directors noted that the banking system continues to recover. However, the rapid increase of non-resident deposits (NRDs) warrants vigilance, given that it represents a source of vulnerability to international reserves and a contingent fiscal liability. Directors welcomed higher minimum capital requirements for NRD-specialized banks, and recommended continued intensive and frequent supervision. Directors looked forward to completion of the banking sector restructuring, and noted that a new FSAP would be useful to take stock of the transformation since the crisis.

Directors welcomed the authorities' strong commitment to euro adoption and commended the progress towards meeting the Maastricht criteria. They noted however that continued strong implementation of structural reforms will be necessary to address high structural unemployment and enhance competitiveness. Priorities for action are reforms to the judicial system, the governance structure and transparency of state-owned enterprises, and the quality of higher and vocational education.

Directors agreed with the conclusions of the ex post evaluation. They concurred that the immediate program objectives were achieved and that important progress was made in meeting longer-term objectives. Key supporting elements included strong ownership by the authorities, significant support by the international community, including a large financing package, effective engagement by the private sector, an explicit and credible exit strategy, and a flexible program design. Directors also agreed that the case of Latvia shows the importance of adequately accounting for real-financial linkages in estimating the impact of financial stress on real activity and in program design.

\section{Ex-Post Evaluation}

The economic boom in Latvia that began in 2000 and accelerated following accession to the European Union in 2004 proved unsustainable. Large private sector inflows fueled rapid economic growth driven mainly by domestic demand in the nontradeable sector. Inflation accelerated, a real estate bubble developed, and a large current account deficit opened. The accompanying increase in foreign indebtedness, which financed domestic credit expansion, led to the buildup of vulnerabilities particularly in the banking sector and heightened financial account risks.

By early 2008 , the fast growth was leveling off but severe vulnerabilities turned the slowdown into a crisis. Capital flows came to a sudden stop as global liquidity tightened. Uncertainty regarding the financial condition of the largest domestically-owned bank led to a run on its deposits and a severe system-wide liquidity shortage. These pressures were compounded by concerns over the sustainability of the currency peg. In November, the authorities turned to the IMF and the European Commission for financial support to avert a systemic bank failure, prevent further decline in international reserves that could threaten the sustainability of the peg, and address the 
deterioration in the fiscal position in the face of the decline in economic activity. The Stand-By Arrangement (SBA) was approved in December 2008 with an exceptional access of SDR 1.52 billion, equivalent to 1,200 percent of quota-one of the largest in Fund history at the time, with significant co-financing from other partners including the European Union and regional partners.

Public Information Notices (PINs) form part of the IMF's efforts to promote transparency of the IMF's views and analysis of economic developments and policies. With the consent of the country (or countries) concerned, PINs are issued after Executive Board discussions of Article IV consultations with member countries, of its surveillance of developments at the regional level, of post-program monitoring, and of ex post assessments of member countries with longer-term program engagements. PINs are also issued after Executive Board discussions of general policy matters, unless otherwise decided by the Executive Board in a particular case. The staff report (use the free Adobe Acrobat Reader to view this pdf file) for the 2012 Article IV consultation and Second Post-Program Monitoring Discussions with the Republic of Latvia. 


\begin{tabular}{|c|c|c|c|c|c|}
\hline & 2009 & 2010 & 2011 & 2012 & 2013 \\
\hline & & & & \multicolumn{2}{|c|}{ Projections } \\
\hline \multicolumn{6}{|l|}{ Real Economy } \\
\hline Real GDP (percentage change) & -17.7 & -0.9 & 5.5 & 5.2 & 3.7 \\
\hline HICP inflation (percentage change, period average) & 3.3 & -1.2 & 4.2 & 2.4 & 2.2 \\
\hline Unemployment rate (period average, percent) $1 /$ & 18.2 & 18.7 & 16.2 & 15.0 & 13.7 \\
\hline Nominal GDP (billions of lats) & 13.1 & 12.8 & 14.3 & 15.3 & 16.3 \\
\hline Public Finance 2/ & \multicolumn{5}{|c|}{ (percent of GDP, unless otherwise indicated) } \\
\hline Total Revenue & 36.2 & 36.0 & 35.6 & 38.0 & 35.4 \\
\hline Total Expenditure & 43.3 & 42.4 & 38.7 & 38.7 & 36.6 \\
\hline Basic fiscal balance & -7.1 & -6.4 & -3.1 & -0.7 & -1.2 \\
\hline ESA balance & -9.7 & -8.2 & -3.4 & -1.8 & -1.7 \\
\hline General government gross debt & 32.9 & 39.7 & 37.5 & 37.6 & 42.2 \\
\hline \multicolumn{6}{|l|}{ Balance of payments } \\
\hline Trade balance & -7.1 & -7.0 & -10.7 & -11.9 & -12.3 \\
\hline Current account balance & 8.7 & 3.0 & -2.1 & -2.2 & -3.4 \\
\hline Gross official reserves (billions of euros) & 4.8 & 5.8 & 4.9 & 5.4 & 6.7 \\
\hline Gross external debt & 156.8 & 165.1 & 143.9 & 138.3 & 137.2 \\
\hline Net external debt $3 /$ & 58.8 & 54.2 & 46.0 & 39.5 & 35.1 \\
\hline \multicolumn{6}{|l|}{ Exchange rates } \\
\hline Lats per U.S. dollar (average) & 0.506 & 0.530 & 0.501 & $\ldots$ & ... \\
\hline Lats per euro (average) & 0.704 & 0.704 & 0.697 & $\ldots$ & ... \\
\hline REER (period average; CPI based, $2000=100$ ) & 110.2 & 103.6 & 103.8 & $\ldots$ & ... \\
\hline (percent change,+ denotes appreciation) & 5.5 & -6.0 & 0.2 & $\ldots$ & ... \\
\hline \multicolumn{6}{|l|}{ Money and Credit } \\
\hline Broad money (percentage change) & -1.9 & 9.8 & 1.5 & 2.5 & 6.6 \\
\hline Credit to private sector (percentage change) & -6.9 & -8.4 & -7.4 & -9.0 & 1.2 \\
\hline Treasury Bill rate (365 days, eop, percent) & 10.2 & 1.8 & 1.7 & $\ldots$ & ... \\
\hline Money market rate (one month, eop, percent, annualized) & 2.7 & 0.6 & 1.1 & $\ldots$ & $\cdots$ \\
\hline
\end{tabular}

Sources: Latvian authorities, Eurostat, and IMF staff estimates.

1/ LFS statistics were revised in 2011 in compliance with population census; data before 2011 have not been revised yet.

2/ National definition. Includes economy-wide EU grants in revenue and expenditure.

3/ Gross external debt minus gross external debt assets. 


\section{Statement by Mr. Benny Andersen, Executive Director, and Mr. Gundars Davidsons, Senior Advisor to the Executive Director on the Republic of Latvia \\ January 23, 2013}

On behalf of the Latvian authorities, we thank staff for the excellent analysis provided in the reports and the selected issues papers. The Latvian authorities have always given careful consideration to policy recommendations coming from the Fund. Also this time, the authorities and staff had fruitful discussions and staff provided a valuable insight on the economy's risks and challenges. Though the views differed on some minor points, the Latvian authorities broadly agree with the views outlined in the Article IV/PPM and ExPost Evaluation reports. In the following few paragraphs we will try to convey the authorities' views on various subjects discussed during the staff visits.

\section{Economic outlook}

Still riding the wave generated by the Latvian authorities' decisive actions of 2009/2010 the economy continued to surprise on the upside. Despite the headwinds from the sovereign debt crisis and the still-ongoing deleveraging, the slowdown we had been expecting all through 2012 has not materialized. The exports sector performed better than expected, and the $3^{\text {rd }}$ quarter GDP figure, at 5.2 percent (y-o-y), added yet another quarter of Latvia heading the list of the EU's best growth performers. The recent data indicate this rapid growth trend, though gradually decelerating, was continuing also in the $4^{\text {th }}$ quarter. Recognizing that this growth is largely a rebound from the excessive drop during the crisis and has its roots in the hysteria of 2009, the authorities project a gradual slowdown in 2013, in line with staff views.

\section{End of Latvia's 2008 SBA}

The repayment of the remaining debt to the Fund closes the chapter on Latvia's 2008 Stand-By Arrangement. The economy has indeed experienced a profound change: the exchange rate is now broadly in line with fundamentals, and the current account and public deficits are at comfortable levels. The fact that the repayment to the Fund was financed by a US dollar bond issuance at a yield of 2.9 percent illustrates that this revival has also been recognized by markets. The most significant cost of the crisis is the increase in emigration. While the problem is not new, Latvia was an emigration country even during the boom years, finding a way to curb emigration and make the country a more attractive place to live will be one of the toughest challenges the authorities will face in the coming decades. In this context, we found the discussion in Appendix II on demographic challenges particularly interesting.

More information on the authorities' views on the program and the Ex-Post Evaluation can be found in the Annex to Latvia's "Ex-Post Evaluation of Exceptional Assess Under the 2008 Stand-By Arrangement" paper. 


\section{Article IV consultation and PPM discussions}

On most key Article IV consultation issues, the authorities and staff were on the same page. On the fiscal policy, monetary policy stance, exchange rate assessment, structural reforms, and the challenges in the financial sector the views did not differ substantially. Three issues were discussed more thoroughly, and therefore, warrant a closer look: the changes in the guaranteed minimum income (GMI) benefit provision, the envisaged PIT reductions, and the increase of non-resident deposits (NRDs).

- The discussion on the GMI benefit was probably the closest to what can be called contentious, though from the authorities' perspective, the differences are not as significant as they may seem. The Latvian authorities have always considered the centralization of the GMI benefit as a temporary crisis measure to be unwound as the crisis ends. They also believe that there is a strong rationale for a decentralized GMI benefit system, since municipalities are better placed to assess the needs and incentives of particular individuals. That said, the Latvian authorities do believe that the current degree of inequality is unacceptable and the high level of poverty, tracing back to the collapse of the Soviet Union, should be reduced. The GMI benefit changes, however, should be a part of a more comprehensive reform effort addressing the challenges faced not only by social assistance clients but also low-income households in general. The upcoming World Bank report "Latvia: Who is Unemployed, Inactive or Needy? Assessing Post-Crisis Policy Options" will serve as guidance for further work. If strong arguments are put forward, the Latvian authorities do not exclude re-introduction of some elements of a centralized GMI. For 2013, the government is confident that municipalities will be able to provide the benefit in full. It should be noted that in line with the agreement between Cabinet of Ministers and Association of Local Governments, the 2013 budget law includes transfers to the poorest municipalities. Besides, the government has also committed to support municipalities should their personal income tax revenues fall below planned targets.

- The authorities are determined to implement the PIT cuts as planned. The aim of the rate reductions is to reduce labor costs, with the broader goals of unemployment reduction and improvement in competitiveness in sight. The agreement on the PIT cuts was a difficult compromise decision and is currently supported by the business community and other stakeholders.

- The Latvian authorities are taking steps to mitigate the risks associated with the recent increase of NRDs. While the authorities' thinking is very much in line with that of staff, it should be noted that against the backdrop of the past experience, the current level of the deposits is high, but not extraordinarily high. That said, the Latvian authorities agree that particular vigilance is warranted and, as outlined in the report, are taking measures to reduce the risks. The FCMC has set higher capital requirements for banks specialized in non-resident clients and 
has taken other steps to strengthen liquidity risk management in those banks. The supervision of activities related to non-resident clients has also been significantly strengthened. The Latvian authorities stand ready to introduce additional measures if the NRD-associated risks increase.

\section{The road ahead}

The authorities' commitment to euro adoption remains unwavering. The Latvian authorities are committed to meet the Maastricht criteria in a sustainable way and are comforted by the ECB and EC assurances that the criteria will be applied in an economically meaningful manner.

Efforts to reduce the unacceptably high rate of unemployment will continue. The unemployment rate has declined considerably, from the peak of over 20 percent to 13.5 percent in the $3^{\text {rd }}$ quarter of 2012 (seasonally adjusted 14.1 percent). Since we agree with staff that most of the remaining unemployment is structural in nature, achieving a further reduction will be increasingly difficult. Nevertheless, the authorities intend to take additional steps to decrease unemployment. A new targeted grant scheme for companies expanding employment in selected sectors was launched in the last quarter of 2012 and measures to facilitate regional mobility are in the pipeline. The authorities have also continued to refine the existing active labor market measures gearing employment incentives and training programs more towards the skills demanded by employers. The above-mentioned World Bank study is progressing and the first results are expected in a few months. This study is expected to provide a clearer picture of the extent of long term and structural unemployment, poverty and inequality and serve as guidance for future policy changes.

The crisis has triggered a broad range of potentially growth-enhancing reforms in key sectors. Significant changes are envisaged in higher and vocational education, the judicial system, the management of state-owned enterprises, and in competition policy. The Selected Issues paper covers those issues in great detail, properly reflecting the challenges the Latvian authorities face and the authorities' future plans. We place a high value on staff's interest and assessment on such subjects. Staff rightly points out that the reforms in the higher education sector are already meeting strong insider resistance. Sustaining the reform momentum in a more benign environment will be the authorities' main domestic challenge in the years to come. 